\title{
Issue 42 (May 2019)
}

ISSN 2627-9827 - DOI 10.21570/EDGG.PG.42

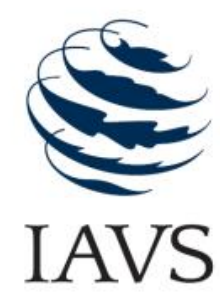

( )

ค

$\sum$

음

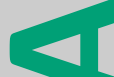

10

(ก)

(ก) $\frac{\pi}{4}$

$\rightarrow$ n

0 남

(1) ลั

(1) $\frac{\frac{5}{\pi}}{\mathrm{n}}$

ए

政

$1 \frac{5}{ \pm}$

140

1

-1 은

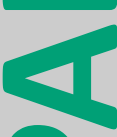

Q 


\section{Table of Contents}

Editorial

Results of the election to the Executive Committee of the EDGG 2019-2021

New members of the Editorial Board

Photo Story and Photo Competition

Grassland Art Competition

Vrahnakis, M. Ten years of Eurasian Grassland Conferences: a vehicle for the future of the EDGG

Yaida, Y.A. et al. Ski runs as an alternative habitat for threatened grassland plant species in Japan

Best Shots on "Grassland closeup"

Short contributions

Book Reviews

Recent Publications of our Members

Forthcoming Events

About EDGG

\section{Palaearctic Grasslands}

ISSN 2627-9827

DOI 10.21570/EDGG.PG41

Palaearctic Grasslands, formerly published under the names Bulletin of the European Dry Grassland Group (Issues 1-26) and Bulletin of the Eurasian Dry Grassland Group (Issues 27-36) is the journal of the Eurasian Dry Grassland Group (EDGG). It usually appears in four issues per year. Palaearctic Grasslands publishes news and announcements of EDGG, its projects, related organisations and its members. At the same time it serves as outlet for scientific articles and photo contributions.

Palaearctic Grasslands is sent to all EDGG members and, together with all previous issues, it is also freely available at http://www.edgg.org/publications.htm.

The copyright of the included texts, photographs, and other figures remains with their authors. If you wish to re-use them or parts of them, please, obtain the written consent of the authors first.

Scientific articles (Research Articles, Reviews, Forum Articles, Scientific Reports) should be submitted to Jürgen Dengler (juergen.dengler@uni-bayreuth.de), following the Author Guidelines published in Palaearctic Grasslands 37, 6-8. They are subject to editorial review, with one member of the Editorial Board serving as Scientific Editor and deciding about acceptance, necessary revisions or rejection.

All other text contributions (News, Announcements, Short Contributions, Book Reviews,...) should be submitted to Anna Kuzemko (anyameadow.ak@gmail.com) AND Idoia Biurrun (idoia.biurrun@ehu.es). Please check a current issue of Palaearctic Grasslands for the format and style. Deadline for submission to the next issue is 1 August 2019

Photo and art contributions (for general illustrative purposes with captions; proposals for Photo Stories; contributions to Photo and Art Competition) should be submitted to both Photo Editors, Rocco Labadessa (rocco.labadessa@gmail.com) AND Jalil Noroozi (noroozi.jalil@gmail.com). Deadline for submissions to the next Photo Competition on "Grassland plant communities" and Art Competition is 1 August 2019.

Contributions to the sections "Recent Publications of our Members" and "Forthcoming Events" should be sent to Iwona Dembicz (iwodem@op.pl).

Photos included in submissions have always to be delivered in two forms, embedded in the document and as separate jpg (or tiff) files with sufficient resolution for printing (i.e. not less than $1 \mathrm{MB}$ ).

Palaearctic Grasslands is published by EDGG c/o Prof. Dr. Jürgen Dengler, Plant Ecology, BayCEER, University of Bayreuth, Universitätsstr. 30, 85447 Bayreuth, Germany.

\section{Editorial Board}

CHIEF EDITOR:

Anna Kuzemko, Ukraine

\section{DEPUTY CHIEF EDITORS:}

Idoia Biurrun, Spain

Jürgen Dengler, Switzerland

\section{EDITORAL BOARD:}

Alla Aleksanyan, Armenia Didem Ambarl,, Turkey Dolores Byrne, Ireland Iwona Dembicz, Poland Edy Fantinato, Italy

Magdalena Firganek-Fulcher, UK

Paul Goriup, UK

Riccardo Guarino, Italy

Richard Jefferson, UK

Gwyn Jones, UK
Rocco Labadessa, Italy Frank Yonghong Li, China Ashley Lyons, UK Lorna Marcham, UK Jim Martin, Ireland James Moran, Ireland Jalil Noroozi, Austria Arkadiusz Nowak, Poland Salza Palpurina, Bulgaria Nina Polchaninova, Ukraine Solvita Rūsiṇa, Latvia Stuart Smith, UK Laura Sutcliffe, Germany Péter Török, Hungary Atushi Ushimaru, Japan Orsolya Valkó, Hungary Stephen Venn, Finland 


\section{Editorial}

Dear readers,

Last year, we celebrated an important anniversary ten years of our group's annual meetings, now called the Eurasian Grassland Conferences. In this issue, you will find an article by the outgoing long-term conference coordinator, Michael Vrahnakis, on the history of these conferences, which we hope will bring many pleasant memories to the participants of previous meetings. While our recent conference this year in Graz, which many of you attended, is not included in the article, we would like to highlight the success of both the meeting and the additional activities, especially the fantastic post-conference excursion in Slovenia.

We are also publishing a research article by a group of authors from Japan in which grassland conservation is viewed from a somewhat unusual angle: they demonstrate how ski resorts can not only cause biodiversity loss, but also serve as harbors for rare grassland species.
We are pleased to present the winners of the latest photo contest with the topic theme of "Grassland close-up". We would and also like to draw your attention to the fact that the deadline for accepting artwork for participation in the Grassland Art Competition has been extended. Included in this issue, after a break, are several book reviews, particularly a review of "Grasslands of the World. Diversity, Management and Conservation", which contains a significant contribution from the EDGG. Finally, this issue contains the results of the Executive Committee elections for the period 2019-2021, announcements of new conferences and publications, and other useful information.

We hope that in the midst of the field season you will find time for some fascinating reading, which will allow you not only to relax in your infrequent minutes of rest, but also to inspire new scientific achievements and grassland related creation.

Anna Kuzemko, Chief Editor anyameadow.ak@gmail.com

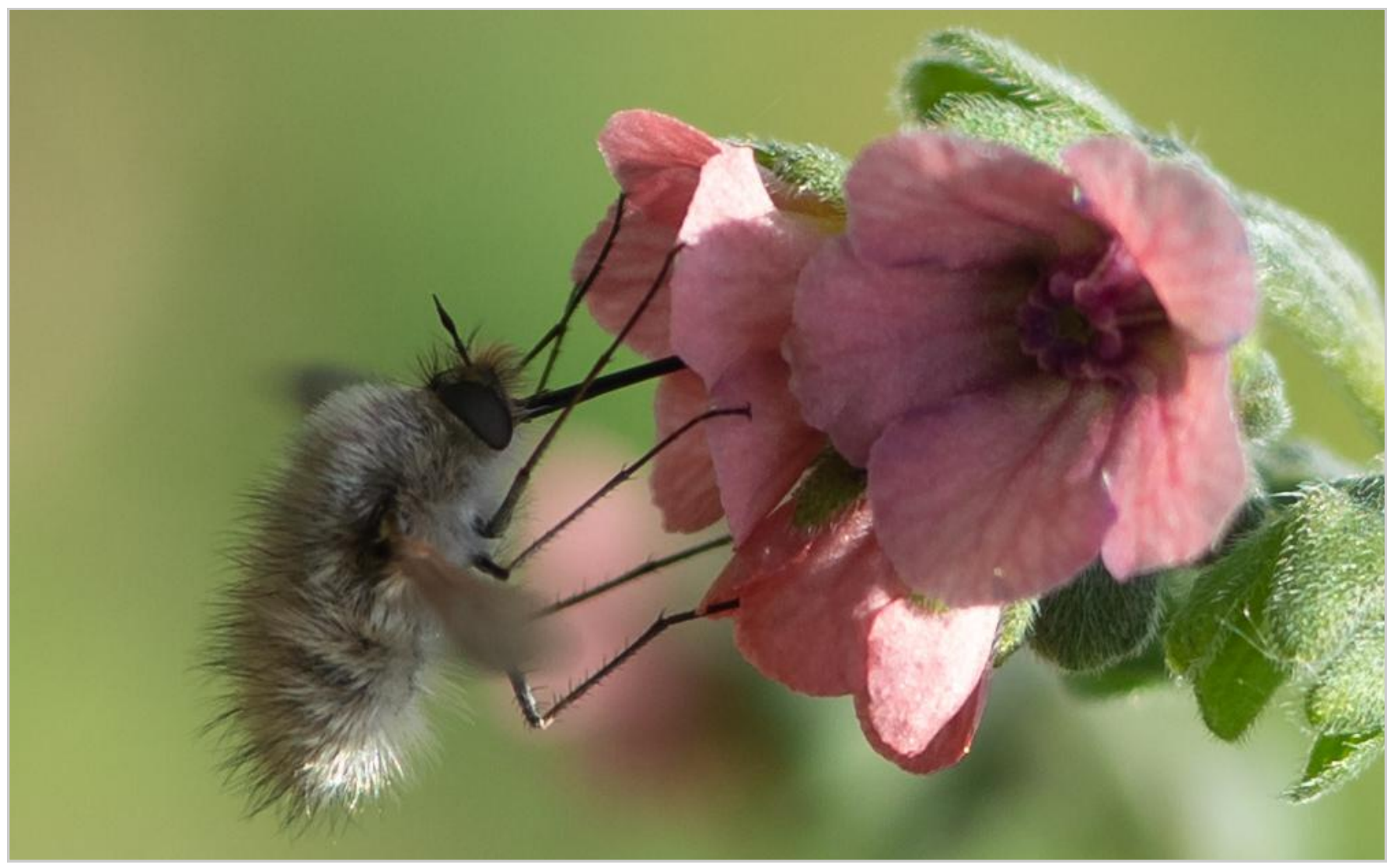




\section{News}

\section{Results of the election to the Executive Committee of the EDGG 2019-2021}

The election for the Executive Committee of the EDGG for 2019-2021 has now closed. A total of 983 votes were cast by 191 voters, which comprises $15 \%$ of those eligible to vote. This is an increase of $5 \%$ since the 2017 election, so it is really great to see that our members are becoming more active and involved. The results of the election are as follows, in the order of the number of votes received:

\begin{tabular}{lcccc}
\hline \multicolumn{1}{c}{ Candidate } & Count & Percentage & Rank & Elected \\
\hline Idoia Biurrun & 140 & 14.2 & 1 & $\mathrm{x}$ \\
Jürgen Dengler & 124 & 12.6 & 2 & $\mathrm{x}$ \\
Anna Kuzemko & 118 & 12.0 & 3 & $\mathrm{x}$ \\
Stephen Venn & 115 & 12.0 & 4 & $\mathrm{x}$ \\
Péter Török & 111 & 11.3 & 5 & $\mathrm{x}$ \\
Didem Ambarli & 84 & 8.5 & 6 & $\mathrm{x}$ \\
Iwona Dembicz & 84 & 8.5 & 6 & $\mathrm{x}$ \\
Alla Aleksanyan & 60 & 6.1 & 8 & $\mathrm{x}$ \\
Salza Palpurina & 59 & 6.1 & 9 & \\
Rocco Labadessa & 51 & 5.2 & 10 & \\
Frank Yonghong Li & 37 & 3.8 & 11 & \\
\hline
\end{tabular}

Idoia received the highest number of votes, at 140 . Interestingly there was a tie for 6th position. The result is that Idoia, Jürgen, Anna, Stephen, Péter, Didem, Iwona and Alla are elected to the Executive Committee for the term 20192021. According to the EDGG bylaws Article $4.2 f$ Those seven candidates with the highest number of votes are elected. In the case of a tie on the seventh position, all candidates with the same number of votes are elected. In order to improve geographic representativeness, the one member based in Europe (in a physical-geographical sense) and the one based outside Europe with the highest number of votes shall be elected even if they are not among the seven with the overall highest number of votes. Therefore Alla, as the candidate from outside Europe with the highest number of votes, is also elected.
We would like to thank all of the candidates and those who voted in the election and congratulate all those candidates who have been elected. We would also like to thank Salza, Rocco and Frank for standing in the election, and we hope they will continue to support the EDGG activities, and that they might be available for future opportunities to participate.

The term of office of the elected chairs will begin at the time of the General Assembly, to be held in Graz, on 1st June, during the 16th Eurasian Grassland Conference. We hope to see as many of you as possible in Graz.

The Executive Committee of the EDGG 


\section{New members of the Editorial Board}

Our team continues to grow. We are pleased to present you two new scientific editors - a long-term member of the Executive Committee Didem Ambarlı and a newly elected EC member - Alla Aleksanyan as well as their vision of the further development of the Palaearctic Grasslands.

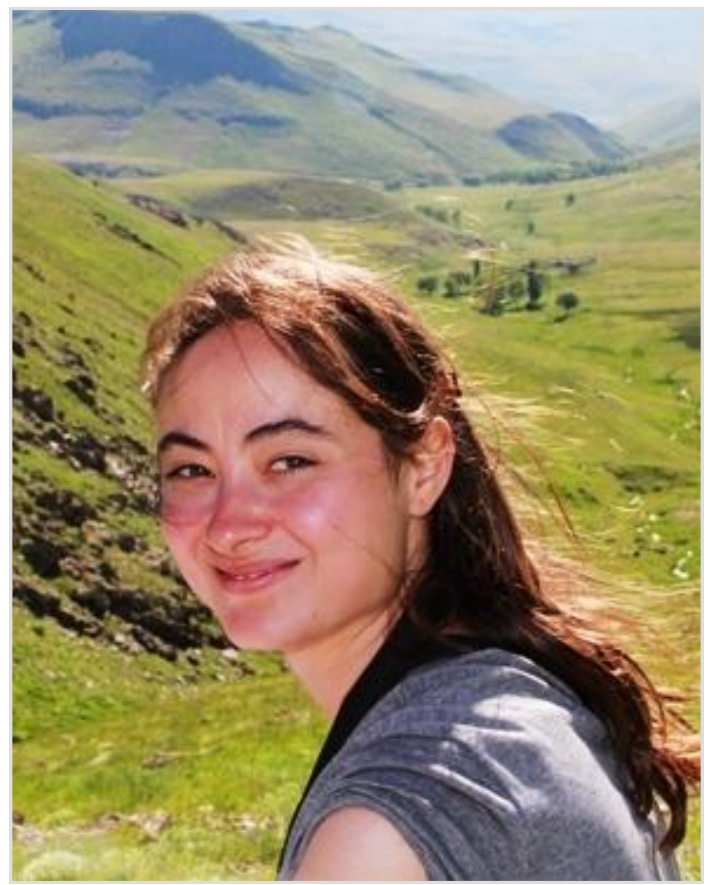

I would like to see Palaearctic Grasslands used more actively by members as a platform to share knowledge and opinions about policy and conservation challenges as well as collaboration opportunities. Furthermore, I would like to see more contributions on ecosystem level research such as ecosystem functions and services.

Didem Ambarlı

didem.ambarli@gmail.com

I would like to see in the future chapter of calls for collaborative joint research and scholarships. Also I suggest to publish success stories of conservation and management of grasslands, which will make journal more attractive and will involve larger audience.

Alla Aleksanyan

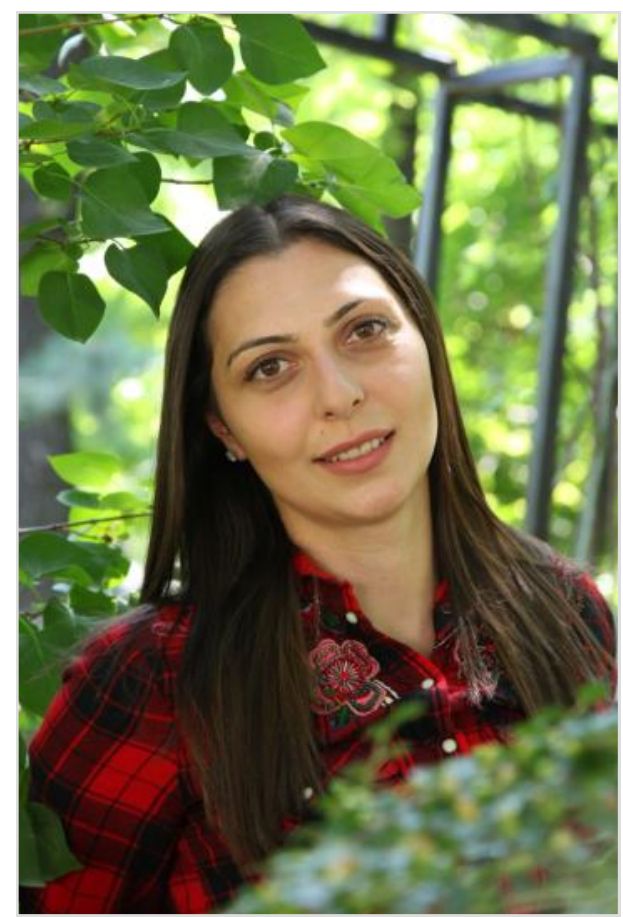




\section{Photo Story and Photo Competition}

In this issue we are pleased to announce a new call for the sections "Photo Story" and "Photo Competition", devoted to the beauty of Palaearctic grasslands.

The call for the current Photo Competition is dedicated to the theme "Grassland plant communities", looking for shots that best highlight the peculiar structure and composition of grassland vegetation types.

You are invited to send up to three high-quality photographs within the competition theme (full size JPEG or TIFF images, at least $300 \mathrm{dpi}$ ) together with captions giving information on the subject (species name, date, place name) and, possibly, technical details (camera, lens, aperture and exposure time).

The selection will be made by a jury of at least five members from the Editorial Board of the journal. The three best shots will be awarded with full space in the next issue, but we reserve the right to use further submitted materials for illustrative purposes in other parts of the issue.

If you feel you can contribute with your shots, don't be shy! Everyone can join the competition!
Contributions for the Photo Story section are always welcome. Photo Story is an open space where members can submit their own photo collection on a certain grasslandrelated topic of their choice. High-quality photos should be provided together with their captions (at least species names or landscape description), a brief text and possibly other graphical elements (like a map or a drawing). The selection of photos should fit for 1-4 pages and the proponents should already propose a preliminary layout (in PDF or MS Word format), which will be finally typeset by Editors. As an example, you may take a look at the Photo Stories published in previous PG issues.

If you want to contribute to these sections, or if you simply want to help us enriching the aspect of the journal, please submit your photos or artwork together with required information to Rocco (rocco.labadessa@gmail.com) and Jalil (noroozi.jalil@gmail.com).

Deadline for submissions to next competitions is 1 August 2019.

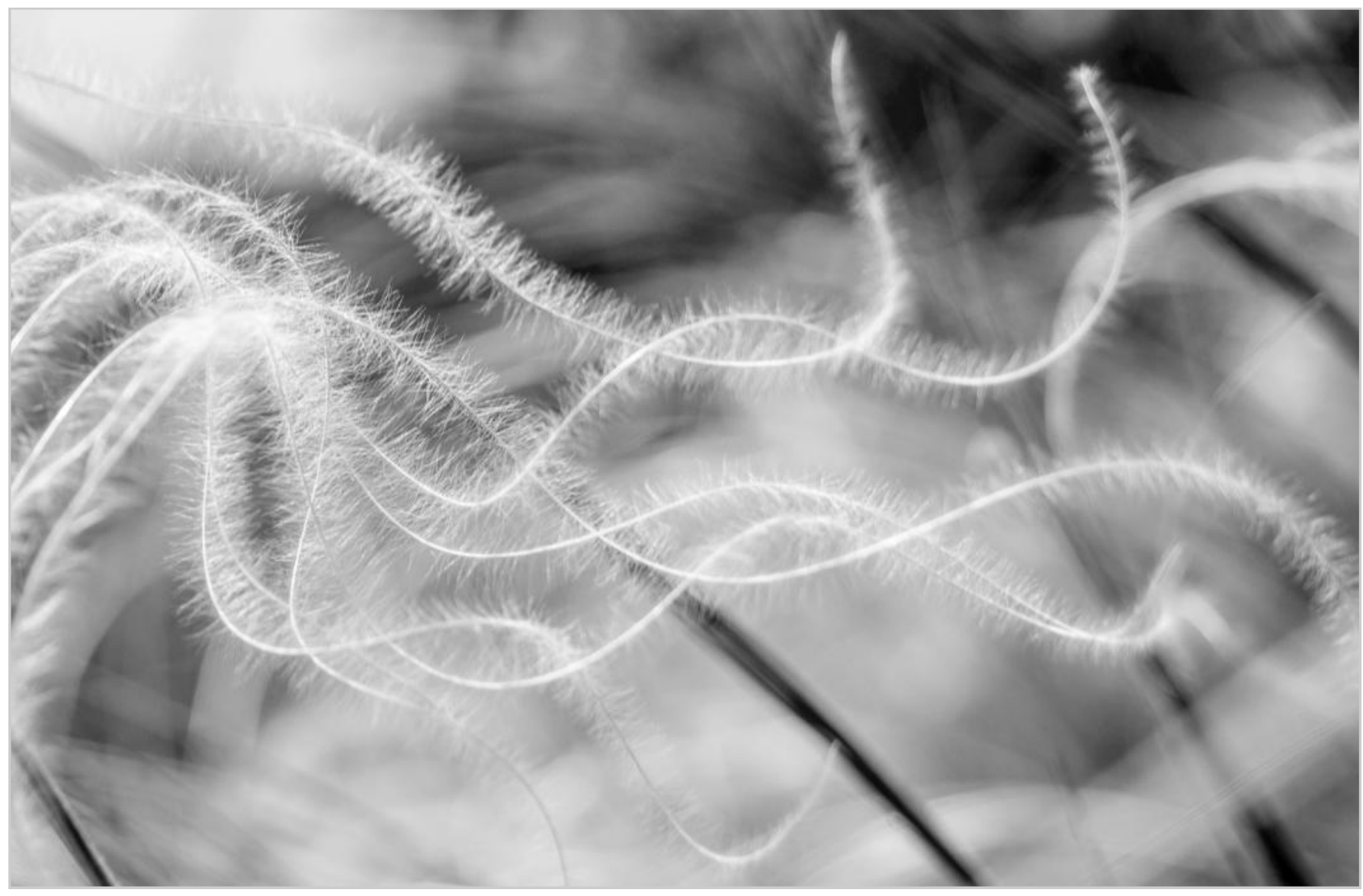

Stipa dasyphylla shapes. Photo: M. Janišová. 


\section{Grassland Art Competition}

Grassland Art Competition is a call for grassland artists, who can challenge each other on a predefined grassland theme. Every kind of drawings or paintings are welcome, with no restrictions regarding realization technique.

With the intention of continuing our exploratory journey in the artistic works of EDGG people, we renovate the wide theme "Grassland subjects". With this theme we are looking for all drawings or paintings regarding grasslands, considering landscapes or details from any point of view. The submission deadline for this theme, which was announced in the previous issue, has been extended to 1 August 2019 in order to give you more time to participate!

If you want to contribute, you are invited to send up to three high-quality images within the competition theme (full size JPEG or TIFF images, at least $300 \mathrm{dpi}$ ) together with descriptions giving information on the title and the technique used. Please submit your photos or artwork together with required information to Rocco (rocco.labadessa@gmail.com) and Jalil (noroozi.jalil@gmail.com).

The selection will be made by a jury of at least five members from the Editorial Board of the journal. The three best works will be awarded with full space in the next issue, but we reserve the right to use further submitted materials for illustrative purposes in other parts of the issue.

Here we can start with some beautiful paintings and drawings by Jürgen Dengler, illustrating grassland subjects with different techniques.

We look forward to seeing many other artworks published in the next issue!
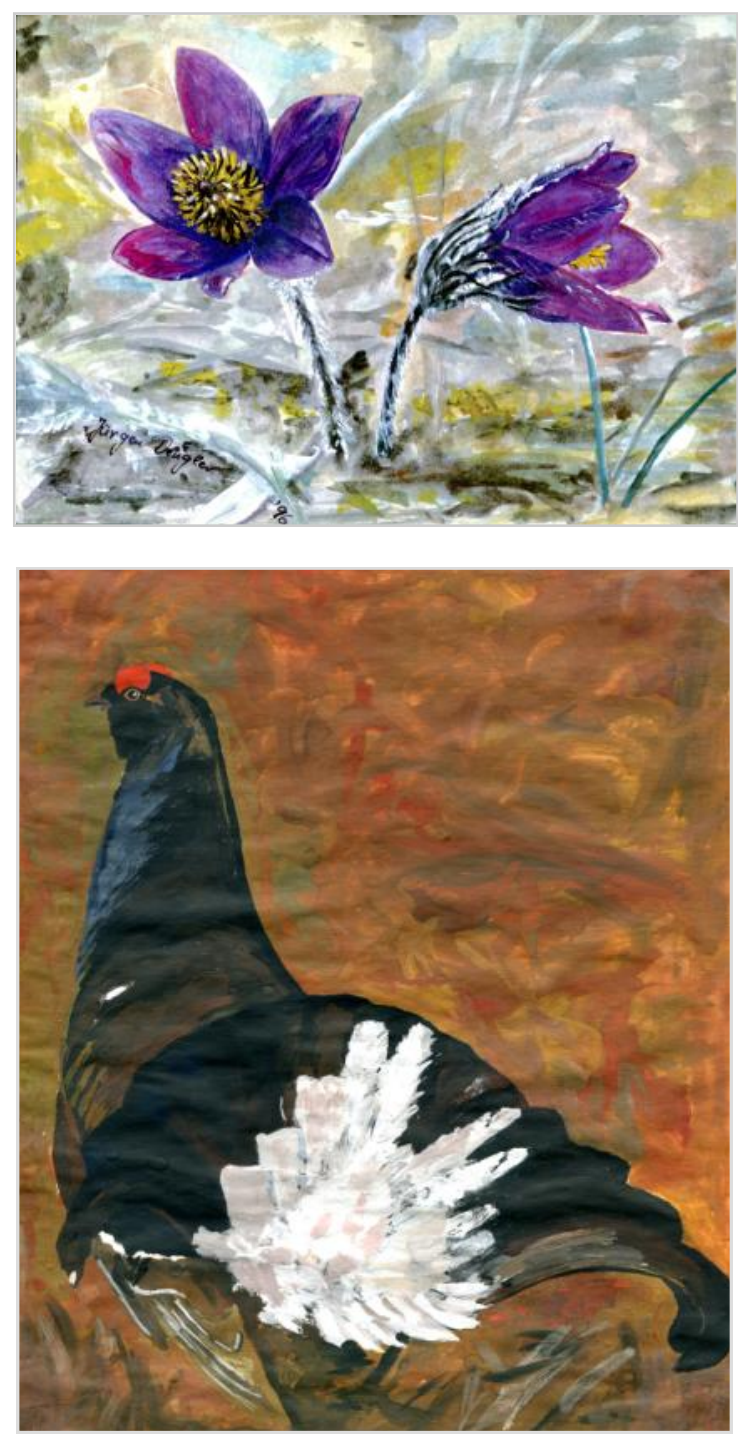

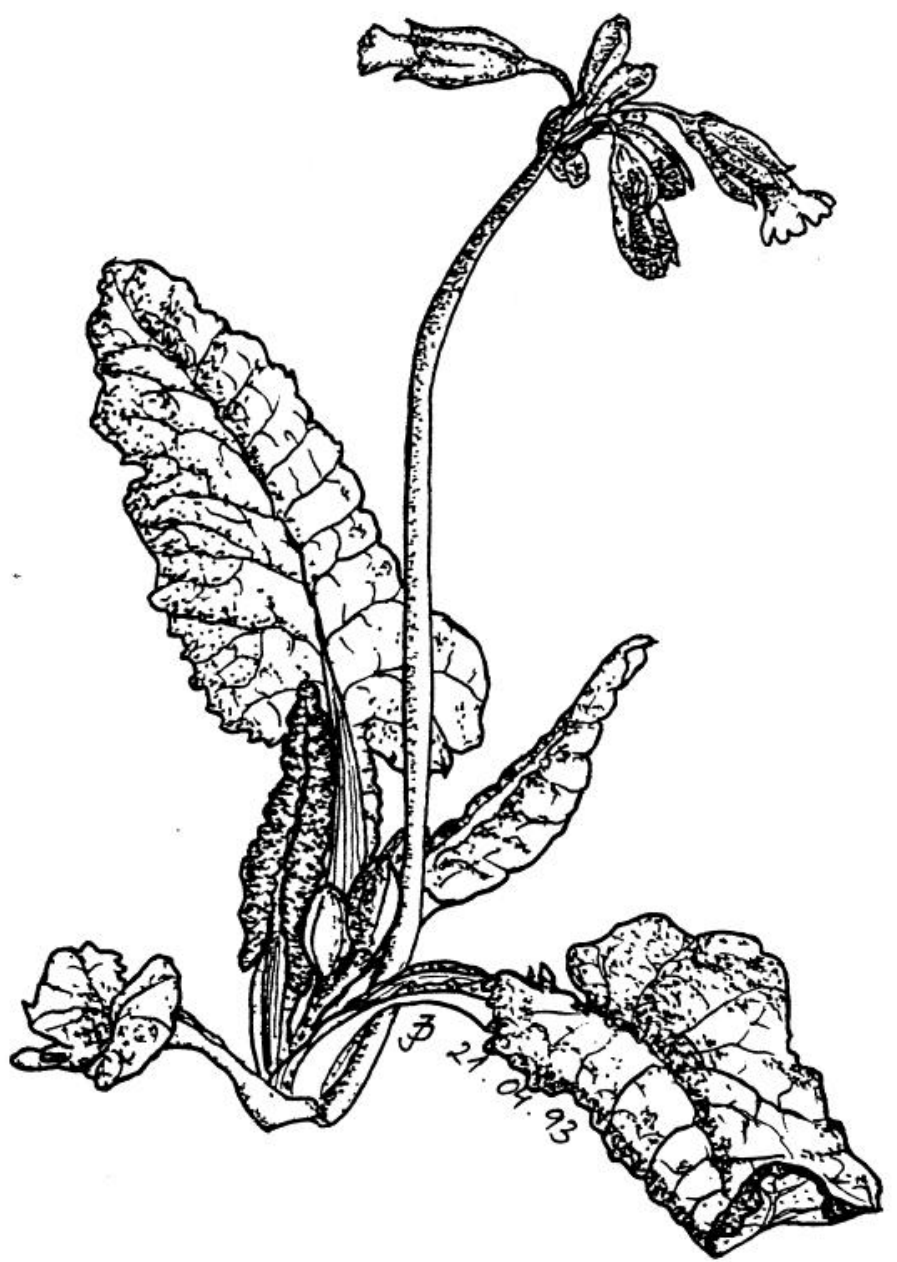

Paintings and drawings by Jürgen Dengler. 


\title{
Ten years of Eurasian Grassland Conferences: a vehicle for the future of the EDGG
}

\author{
Michael Vrahnakis $(0)$
}

Department Forestry, Wood and Design Sciences, School of Technology,

University of Thessaly, Karditsa, 43100, Greece; mvrahnak@teilar.gr

\begin{abstract}
Palaearctic Grasslands 42 (2019): 8-15
Abstract: One of the primary outcomes of the first five annual meetings of the German Arbeitsgruppe Trockenrasen (2004-2008) was the need for internationalization, i.e. to attract scientists together with their knowledge and experience from abroad, at least from EU. Year after year this need became imperative and in the foundation of the European Dry Grassland Group (EDGG) in Kiel (August 2008) the idea for a European conference on dry grasslands was born. The first such conference, namely the 6th European Dry Grassland Meeting (EDGM), took place in 2009 in Halle (Germany). After Halle, six more annual EDGMs (in Slovakia, Ukraine, Greece, Poland, Russia, Germany) took place in consecutive years, upgrading the name of EDGG at the European level, and increasing the volume of its mem bership. In the summer of 2015, the EDGG boosted its internationalization by changing its name to Eurasian Dry Grassland Group and renamed its annual meeting as Eurasian Grassland Conference (EGC). Throughout the years, and in accordance with EDGG bylaws, the EDGM/EGC remains the main communication tool and one of the core activities of the EDGG. This article was written for the celebration of the tenth anniversary of EDGM/EGC, after its first organization in 2009. It aims to bring into light the communication power that the EGC has, by presenting an overview of past meetings and conferences that served as the main link between EDGG members. The relevant dry grassland meetings before 2009 are briefly presented in the first section of this article; the second section presents the seven EDGMs, and the third section presents an overview of the three EGCs that followed up to now.
\end{abstract}

Keywords: conference; Eurasian Dry Grassland Group (EDGG); Eurasian Grassland Meeting (EGM); grassland; International Association for Vegetation Science (IAVS); Palaearctic; working group.

Abbreviations: $\mathrm{EDGG}=$ Eurasian/European Dry Grassland Group; EDGM = European Dry Grassland Meeting; EGC = Eurasian Grassland Conference.

Submitted: 10 February 2019; first decision: 22 February 2019; accepted: 25 February 2019

Scientific Editor: Solvita Rūsiṇa

Linguistic Editor: Dolores Byrne

\section{Introduction}

Scientific conferences on grasslands and their resources are worldwide and well-established institutions and meeting points. The majority of them are of national interest, while others focus on broader geographic scopes, e.g. the symposia and conferences of European Grassland Federation, or the International Rangeland Congress organized by its Continuing Committee. The annual scientific conference of the EDGG is a scientific forum where ideas related to Eurasian dry grasslands and their resources find fertile ground to develop. Since 2004, the dry grassland meetings organized by EDGG or its ancestor scheme have offered a framework for exchanging ideas about dry grassland classification, management, restoration and protection, discussing and disseminating results of research on dry grasslands, meeting specialists from diverse origins but of common interests, and for developing cooperation with colleagues, old and new. From its inception as a small national event, the EDGG conferences soon gained in size and are becom- ing more and more international (Table 1). The topics change from year to year and are adapted in accordance with the specific objectives and wishes of the local organizing committees. The conferences comprise both oral presentations (sometimes also with invited keynote speakers) and poster sessions. Furthermore, the General Assembly of the EDGG is holding during its conferences. Both the excursions to regionally representative dry grassland habitats in the surroundings of the venue and the "dry grassland party" have become popular elements of the EDGG conferences. The organization of the conferences is approved by the General Assembly of the EDGG and further supported by two members of the Executive Committee, who are standing next to the local organizers through the whole preceding period. To facilitate the whole procedure a Users' Guide on how to organize the conference is published and posted in the web of EDGG (Vrahnakis 2015). The purpose of this article is to show the characteristic moments of the past conferences of the EDGG, from its early years 
Table 1. Historical development of the Eurasian Grassland Conferences (EGCs).

\begin{tabular}{|c|c|c|c|c|c|c|c|}
\hline Year & Meeting & Location & Motto & \# Participants & \# Countries & \# Talks & \# Posters \\
\hline $\begin{array}{c}2004 \\
(24-26 \\
\text { September })\end{array}$ & $\begin{array}{c}1^{\text {st }} \text { Annual Meeting of the } \\
\text { Arbeitsgruppe Trocken- } \\
\text { rasen }\end{array}$ & $\begin{array}{l}\text { Lüneburg } \\
\text { (Germany) }\end{array}$ & $\begin{array}{l}\text { Dry Grasslands as Biodiver- } \\
\text { sity Hotspots }\end{array}$ & 31 & 1 & 10 & 10 \\
\hline $\begin{array}{c}2005 \\
\text { (26-28 August) }\end{array}$ & $\begin{array}{c}2^{\text {nd }} \text { Annual Meeting of the } \\
\text { Arbeitsgruppe Trocken- } \\
\text { rasen }\end{array}$ & $\begin{array}{c}\text { Münster } \\
\text { (Germany) }\end{array}$ & $\begin{array}{l}\text { Observation Scales in Dry } \\
\text { Grasslands }\end{array}$ & 33 & 3 & 11 & 9 \\
\hline 2006 & $\begin{array}{c}3^{\text {rd }} \text { Annual Meeting of the } \\
\text { Arbeitsgruppe Trocken- } \\
\text { rasen }\end{array}$ & $\begin{array}{c}\text { Halle } \\
\text { (Germany) }\end{array}$ & & [cancell & ed] & & \\
\hline $\begin{array}{c}2007 \\
(06-08 \\
\text { September })\end{array}$ & $\begin{array}{l}4^{\text {th }} \text { Annual Meeting of the } \\
\text { Arbeitsgruppe Trocken- } \\
\text { rasen }^{1}\end{array}$ & $\begin{array}{l}\text { Freising } \\
\text { (Germany) }\end{array}$ & $\begin{array}{l}\text { Restoration and Spontane- } \\
\text { ous Establishment of Dry } \\
\text { and Semi-Dry Grasslands at } \\
\text { Traditional and Urbanin- } \\
\text { dustrial Sites }\end{array}$ & 49 & 2 & 13 & 6 \\
\hline $\begin{array}{c}2008 \\
\text { (28-30 August) }\end{array}$ & $\begin{array}{l}5^{\text {th }} \text { Annual Meeting of the } \\
\text { Arbeitsgruppe Trocken- } \\
\text { rasen and the } 1^{\text {st }} \text { Meeting } \\
\text { of the Working Group on } \\
\text { Dry Grasslands in the Nor- } \\
\text { dic and Baltic Region }{ }^{2}\end{array}$ & $\begin{array}{c}\text { Kiel } \\
\text { (Germany) }\end{array}$ & $\begin{array}{l}\text { Dry Grasslands in a Chang- } \\
\text { ing Environment }\end{array}$ & 44 & 10 & 10 & 15 \\
\hline
\end{tabular}

28 August 2008: Foundation of the European Dry Grassland Group (EDGG) in Kiel's meeting ${ }^{3}$ Autumn 2008 - Election of the first Executive Committee of the EDGG

\begin{tabular}{ccccc}
\hline $\mathbf{2 0 0 9}$ & $6^{\text {th }}$ European Dry Grass- \\
land Meeting & $\begin{array}{c}\text { Halle } \\
\text { September) }\end{array}$ & $\begin{array}{c}\text { Dry Grasslands - Species } \\
\text { (Germany) }\end{array}$ & $\begin{array}{c}\text { Interactions and Distri- } \\
\text { bution }\end{array}$ & 11 \\
\hline
\end{tabular}

1 September 2009: EDGG became a Working Group of International Association for Vegetation Science (IAVS) after the official offer of its president Prof. Robert Peet

\begin{tabular}{|c|c|c|c|c|c|c|c|}
\hline $\begin{array}{l}2010 \\
(28 \text { May - } 01 \\
\text { June) }\end{array}$ & $\begin{array}{c}7^{\text {th }} \text { European Dry Grass- } \\
\text { land Meeting }\end{array}$ & $\begin{array}{l}\text { Smolenice } \\
\text { (Slovakia) }\end{array}$ & $\begin{array}{c}\text { Succession, Restoration and } \\
\text { Management of Dry Grass- } \\
\text { lands }\end{array}$ & 100 & 19 & 35 & 38 \\
\hline $\begin{array}{c}2011 \\
(13-17 \text { June) }\end{array}$ & $\begin{array}{c}8^{\text {th }} \text { European Dry Grass- } \\
\text { land Meeting }\end{array}$ & $\begin{array}{l}\text { Uman' } \\
\text { (Ukraine) }\end{array}$ & $\begin{array}{c}\text { Dry Grasslands of Europe: } \\
\text { Biodiversity, Classification, } \\
\text { Conservation and Manage- } \\
\text { ment }\end{array}$ & 80 & 18 & 20 & 33 \\
\hline $\begin{array}{c}2012 \\
(19-23 \text { May) }\end{array}$ & $\begin{array}{c}9^{\text {th }} \text { European Dry Grass- } \\
\text { land Meeting }\end{array}$ & $\begin{array}{l}\text { Prespa } \\
\text { (Greece) }\end{array}$ & $\begin{array}{c}\text { Dry Grasslands of Europe: } \\
\text { Grazing and Ecosystem } \\
\text { Services }\end{array}$ & 120 & 25 & 23 & 100 \\
\hline $\begin{array}{c}2013 \\
(24-31 \text { May) }\end{array}$ & $\begin{array}{l}10^{\text {th }} \text { European Dry } \\
\text { Grassland Meeting }\end{array}$ & $\begin{array}{l}\text { Zamość } \\
\text { (Poland) }\end{array}$ & $\begin{array}{l}\text { When Theory Meets Prac- } \\
\text { tice: Conservation and } \\
\text { Restoration of Grasslands }\end{array}$ & 82 & 16 & 21 & 56 \\
\hline $\begin{array}{c}2014 \\
\text { (05-16 June) }\end{array}$ & $\begin{array}{l}11^{\text {th }} \text { European Dry } \\
\text { Grassland Meeting }\end{array}$ & $\begin{array}{l}\text { Kulikovo } \\
\text { Field, Tula } \\
\text { (Russia) }\end{array}$ & $\begin{array}{c}\text { Steppes and Semi-Natural } \\
\text { Dry Grasslands: } \\
\text { Ecology, Transformation } \\
\text { and Restoration }\end{array}$ & 55 & 10 & 29 & 18 \\
\hline $\begin{array}{c}2015 \\
(22-27 \text { May) }\end{array}$ & $\begin{array}{l}12^{\text {th }} \text { European Dry } \\
\text { Grassland Meeting }\end{array}$ & $\begin{array}{c}\text { Mainz } \\
\text { (Germany) }\end{array}$ & $\begin{array}{l}\text { Population Biology and } \\
\text { Community Ecology of Dry } \\
\text { Grasslands and Dry Grass- } \\
\text { land Species }\end{array}$ & 50 & 15 & 23 & 18 \\
\hline
\end{tabular}

\footnotetext{
${ }^{1}$ Also $2^{\text {nd }}$ Workshop 'Floristics and Geobotany - Contributions to Applied Questions' of the Floristisch-soziologische Arbeitsgemeinschaft ${ }^{2}$ Jointly organised by the Arbeitsgruppe Trockenrasen and the Working Group on Dry Grasslands in the Nordic and Baltic Region ${ }^{3}$ EDGG was established by the fusion of the German Arbeitsgruppe Trockenrasen and the Working Group on Dry Grasslands in the Nordic and Baltic Region
} 
Table 1. Continuation

\begin{tabular}{|c|c|c|c|c|c|c|c|}
\hline Year & Meeting & Location & Motto & \# Participants & \# Countries & \# Talks & \# Posters \\
\hline \multicolumn{8}{|c|}{$\begin{array}{c}\text { Summer } 2015 \text { - European Dry Grassland Group changed to Eurasian Dry Grassland Group - } \\
\text { European Dry Grassland Meeting changed to Eurasian Grassland Conference }\end{array}$} \\
\hline $\begin{array}{c}2016 \\
\text { (20-24 Septem- } \\
\text { ber) }\end{array}$ & $\begin{array}{c}13^{\text {th }} \text { Eurasian Grassland } \\
\text { Conference }\end{array}$ & $\begin{array}{l}\text { Sighişoara } \\
\text { (Romania) }\end{array}$ & $\begin{array}{l}\text { Management and Con- } \\
\text { servation of Semi- } \\
\text { Natural Grasslands: } \\
\text { from Theory to Practice }\end{array}$ & 85 & 25 & 26 & 32 \\
\hline $\begin{array}{c}2017 \\
\text { (04-11 July) }\end{array}$ & $\begin{array}{c}14^{\text {th }} \text { Eurasian Grassland } \\
\text { Conference }\end{array}$ & $\begin{array}{l}\text { Riga (Latvia) } \\
\text { - Western } \\
\text { Lithuania }\end{array}$ & $\begin{array}{l}\text { Semi-Natural Grasslands } \\
\text { across Borders }\end{array}$ & 92 & 19 & 23 & 20 \\
\hline $\begin{array}{c}2018 \\
\text { (04-08 June) }\end{array}$ & $\begin{array}{l}15^{\text {th }} \text { Eurasian Grassland } \\
\text { Conference }\end{array}$ & $\begin{array}{l}\text { Sulmona } \\
\text { (Italy) }\end{array}$ & $\begin{array}{l}\text { Cooperating for Grass- } \\
\text { land Conservation }\end{array}$ & 59 & 18 & 27 & 16 \\
\hline $\begin{array}{l}2019 \\
(29 \text { May - } 05 \\
\text { June) }\end{array}$ & $\begin{array}{c}16^{\text {th }} \text { Eurasian Grassland } \\
\text { Conference }\end{array}$ & $\begin{array}{c}\text { Graz } \\
\text { (Austria) - } \\
\text { Slovenia }\end{array}$ & $\begin{array}{c}\text { Species-Rich Grasslands } \\
\text { in the Palaearctic-a } \\
\text { Treasure without Eco- } \\
\text { nomic Value? }\end{array}$ & 64 & 18 & 32 & 22 \\
\hline
\end{tabular}

up to now, and to highlight its future perspectives in order to achieve the main goals of EDGG.

\section{The early dry grassland conferences (2004-2008)}

The first five annual meetings on dry grasslands were organized by the Arbeitsgruppe Trockenrasen in Germany (2004 in Lüneburg, 2005 in Münster, 2006 in Halle but cancelled, 2007 in Freising, 2008 in Kiel). The group was founded in 2004, having Ute Jandt and Jürgen Dengler as contact persons. The geographic coverage of the group was Germany and was jointly affiliated with AK Syntaxonomy of the Floristisch-soziologische Arbeitsgemeinschaft and the Reinhold-Tüxen-Gesellschaft. The aims of the group were to (i) establish and evaluate of a national vegetation database for dry grassland relevés; (ii) publish of the dry grassland volumes of the series "Synopsis der Pflanzengesellschaften Deutschlands" and (iii) build a platform for research and conservation in German dry grasslands. The starting date of the group was 24 September of 2004 in Lüneburg (Germany), during the 1st Annual Meeting. This meeting had 31 participants, all from Germany. Ten talks and ten posters were presented in Lüneburg. The second meeting of the group took place in Münster (26-28 August 2005), having 33 participants from 3 countries, with 11 talks and 9 posters. The third meeting for 2006 was programed to take place in Halle, but it was cancelled. The fourth meeting took place in Freising (6-8 September 2007); 49 scientists from 2 countries participated, presenting 13 talks and 6 posters. The scientific themes of the meetings covered several aspects of dry grasslands, i.e. on biodiversity (Lüneburg), on restoration and establishment (Freising) or on scaling processes (Münster).

The 5th Dry Grassland Meeting was co-organized by the Arbeitsgruppe Trockenrasen and the Working Group on Dry
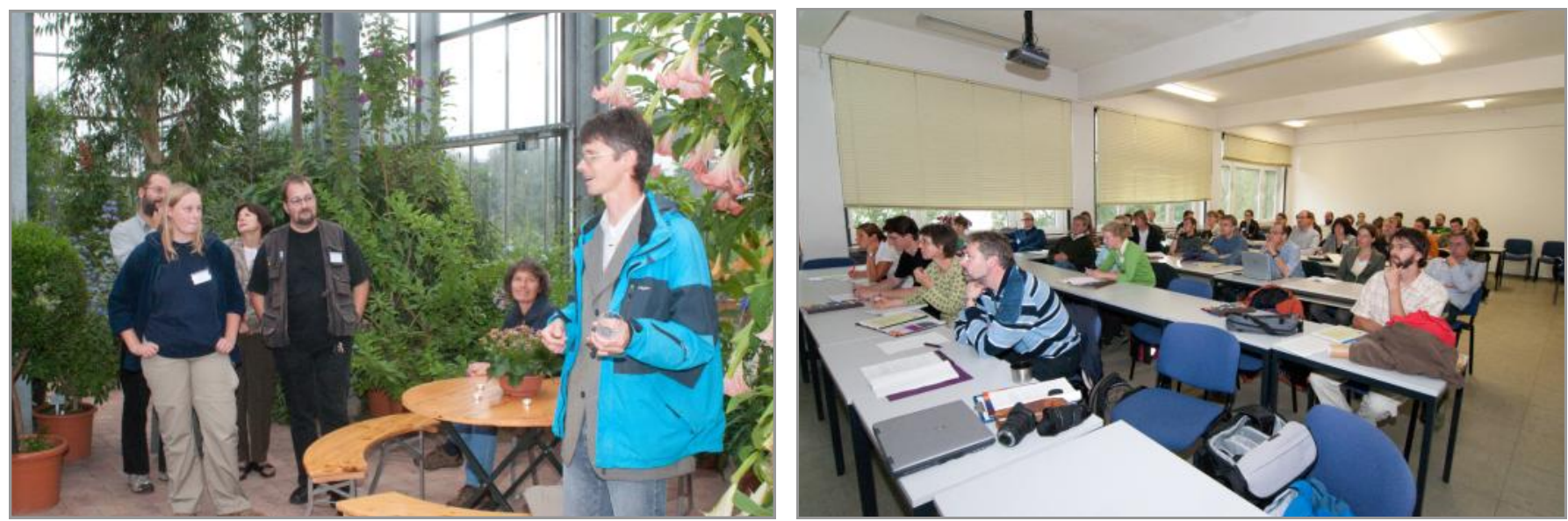

Plate 1. The 5th Annual Meeting of the Arbeitsgruppe Trockenrasen and the 1st Meeting of the Working Group on Dry Grasslands in the Nordic and Baltic Region in Kiel, Germany (2008). Photos: J. Dengler. 

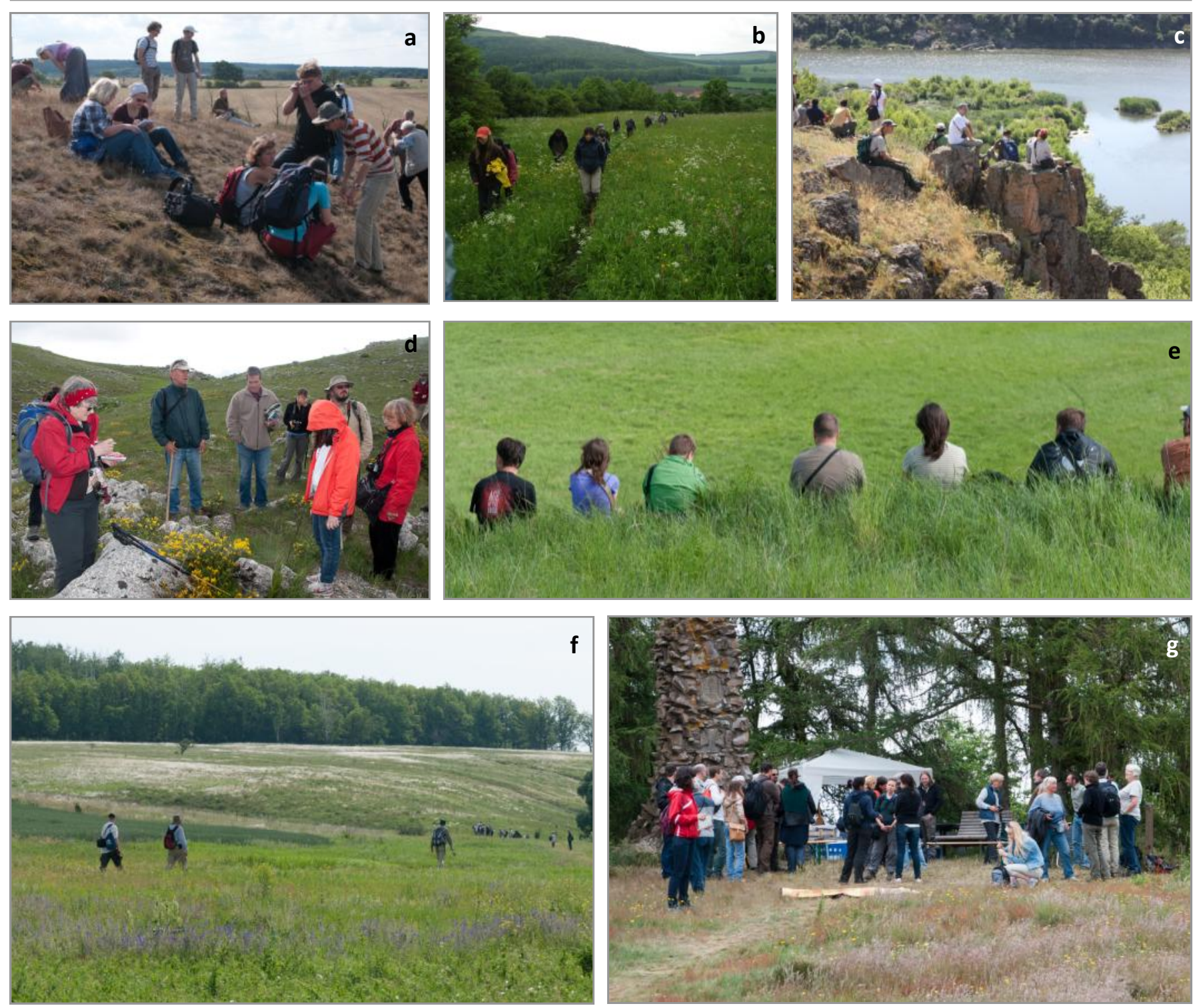

Plate. 2. The European Dry Grassland Meetings (EDGM, 2009-2015): (a) the 6th EDGM in Halle, Germany (2009), (b) the 7th EDGM in Smolenice, Slovakia (2010), (c) the 8th EDGM in Uman', Ukraine (2011), (d) the 9th EDGM in Prespa, Greece (2012), (e) the 10th EDGM in Zamość, Poland (2013), (f) the 11th EDGM in Kulikovo field, Russia (2014), (g) the 12th EDGM in Mainz, Germany (2015). Photos: J. Dengler (a, d, e, f, g), M. Vrahnakis (b), A. Kuzemko (c).

Grasslands in the Nordic and Baltic Region, in Kiel (28-30 August 2008) (Dolnik 2008) (Plate 1). The latter group was founded in 2005 (contact person: Jürgen Dengler) and aimed at establishment and evaluation of a supra-national vegetation database for dry grassland relevés from Denmark, Norway, Sweden, Finland, NW Russia, Estonia, Latvia, Lithuania, N Poland, and NE Germany. The main theme of the conference was on the ways that physical and social changes affect grasslands; 44 specialists from 10 countries participated and 10 talks and 15 posters presented in Kiel. One of the major outcomes of the meeting was the need to engage scientists outside Germany and the Nordic-Baltic region in joint activities. This way, the European Dry Grassland Group (EDGG) was originated (28 August 2008); Jürgen Dengler, Monika Janišová and Solvita Rūsiṇa volunteered to serve as its chairs. EDGG was perceived as an umbrella organization for research and conservation activities in European dry grasslands.
The European Dry Grassland Meetings (EDGMs, 20092015) (Plate 2)

Right after its formation the EDGG organized its $6^{\text {th }}$ EDGM in Halle (Germany), 31 August - 2 September, 2009). The theme was on "Dry Grasslands - Species Interactions and Distribution". Forty people from 11 countries participated, and 15 talks and 17 posters were presented (Anonymous 2009). The topics ranged from population biology and phylogeography of dry grassland species, through regional studies on dry grassland and related vegetation types, diversity patterns, pollination ecology, and simulation studies, to conservation issues. Apart from guided tours through the city's Botanical Garden, an excursion to visit different types of dry grassland on porphyry hills in the surroundings of Halle was also organized. Participants had the opportunity to study the vegetation marked by an overlapping of continental, subatlantic, and widespread 
Central-European species and consists of atlanticsubatlantic dwarf-shrub heaths as well as (sub)continental dry and semi-dry grassland communities. A postconference excursion was organized to the Unstrut valley SW of Halle. Participants visited several nature reserves with stands of Dictamnus albus in forest-edge communities as well as dry and semi-dry basiphilous grasslands.

The first EDGM organized outside Germany took place in Smolenice (Slovakia), 28 May - 1 June 2010. The $7^{\text {th }}$ EDGM focused on applied ecological aspects of dry grasslands their succession, management and restoration (Janišová et al. 2010). The conference was devoted to the memory of Pavel Deván, one of the best Slovak nature conservationists who worked intensively in the Biele Karpaty Mts. The EDGM was attended by 100 scientists from 19 countries; overall 35 talks were given and 38 posters were presented. Ladislav (Laco) Mucina gave a plenary talk with the theme: "Origins and Evolutionary Assembly of Dry Grasslands of Central Europe: Ideas, Data, Perspectives". A guided tour was organized through the Smolenice castle, while next days the participants travel to dry and semi-dry grassland sites in the Tematínske vrchy, Biele/Bílé Karpaty and Malé Karpaty Mts. In the 7th EDGM, the first competitions for the best talk and poster contributions were announced; the winners were $\mathbf{M}$. Wiezik (best talk) and I. Paulini (best poster). During the conference, the text of Smolenice Grassland Declaration was formulated. The Declaration concluded "for a strong and comprehensive Convention on Grassland Conservation in Europe within the framework of the Pan-European Landscape and Biodiversity Strategy, to secure the future of grasslands which provide vital ecosystem services to human society, are home to biodiversity, sources of natural beauty and cultural values." The Declaration was posted on the EDGG's web-page and was signed (freely) by those who supported its ideas.

The biodiversity, classification, conservation and management of dry grasslands of Europe was the main topic of the $8^{\text {th }}$ EDGM which held in the fantastic National Dendrological Park 'Sofiyivka', National Academy of Sciences of Ukraine, Uman', 13-17 June 2011 (Kuzemko 2011). Altogether 80 participants from 18 countries attended 20 talks and 33 posters. The winners for the Young Investigator Prizes (YIPs) for outstanding talks or posters by researchers under the age of 35 were Péter Török and Triin Reitalu (best two talks) and Anikó Csecserits and Orsolya Valkó (best two posters). The excursion program included the most interesting areas of dry grassland in southern Ukraine. In the National Natural Park of "Buz'ky Gard" the participants visited granite rocks in South Buh River valley near the island Gard and were able to see the locality of several narrow-local South-Buh endemics. In the Ingul River valley the participants visited the limestone steppe slopes. In the Biosphere Reserve "Askania-Nova" they saw a huge (in the European context) area of undisturbed steppe and visited the famous Chaplinsky pod - the biggest depression at the Reserve territory, where almost naturalized herds of Przhevalsky horses, bison, antelopes and ze- bras were grazing. In the National Park "Oleshkivs'ki Sands" the participants visited a desert, developed at Kozache-Lagerna Lower-Dnieper area after the 2nd World War, as a result of excessive sheep grazing. Finally, in the botanical reserve "Sagi" the participants visited the typical Near-Black-Sea Pontic sandy steppe, which was of great interest, in comparison to the widespread in Central Europe Pannonian steppes.

The $9^{\text {th }}$ EDGM took place in Prespa area, northwestern Greece, 19-23 May 2012. In total, 220 people registered; more than 120 people participated; 307 authors from 28 countries produced 123 papers (101 posters and 22 talks) and accepted to present either orally or exhibited as poster (Vrahnakis 2012). The main theme of the EDGM was the way that grazing is balancing with ecosystem services. The conference was devoted to Arne Strid, who greatly contributed to the knowledge of the Greek rangeland flora. Arne Strid gave a plenary talk under the theme "All the way: from Theophrastus up to modern flora databasing - A brief historical review". The participants had the opportunity to visit Mt. Devas with more than 900 plant species and $10 \mathrm{EU}$ habitat types and explore the Juniperus excelsa communities. They also visited the isthmus that separates Lakes Micro and Macro Prespa, where xeric sand calcareous grassland are situated, and the island of Agios Achilios. Finally, they visited the calcareous dry grasslands of Mt. Sfika, which supports $13 \mathrm{EU}$ habitat types and more than 1000 plant taxa. YIPs were given to Didem Ambarli, Jana Slancarova and Inge Paulini for the three best talks and loanna Keisoglou, Rocco Labadessa and Andras Kelemen for the three best posters. Apart from bird-watching activities, other peripheral events included an honorary ceremony for Arne Strid, a short boat cruise to the Greek coast of the western lakeshore of Macro Prespa where orthodox hermitages are located and a visit to the byzantine basilica of Agios Achillios. Finally, poems inspired by the calcareous rockiness and humanity of the Mt. Sfika's landscape were told by the poet himself, Julian Hoffmann, and the unique aesthetic value of the Prespa's landscape was presented in the exhibition of works by local painter Vangelis Tamoutselis. For the first time in the history of EDGG conferences, a special volume was published with the full text of all presented and peer reviewed papers (Vrahnakis et al. 2013).

The next year (24-31 May 2013) the $10^{\text {th }}$ EDGM took place in the old town of Zamość (Poland). A total of 82 people from 16 countries participated and attended 21 talks and 56 posters (Chmielewski 2013). The conference was organized within the framework of EU LIFE project "Conservation and restoration of xerothermic grasslands in Poland - theory and practice" and the main topic was "When Theory Meets Practice: Conservation and Restoration of Grasslands". The contributions dealt with dry grassland management measures (grazing, burning, examples and best practices), dry grassland restoration (deliberate and spontaneous) and various theoretical issues. During the lunch and coffee breaks, the participants had an opportunity to enjoy the exhibition entitled "Natura 2000/Lubelskie/PL". Ple- 
nary talks were given by Peter Török "Application of technical grassland restoration in Europe: recovery of grassland biodiversity by seed mixtures at multiple countries and scales" and Simona Bacchereti "LIFE Nature for dry grasslands: examples and best practices". YIPs for best four oral presentations were given to Rocco Labadessa, Philipp Sengl, Verena Rösch and Eleonora Giarrizzo and for the best two posters to Orsolya Valkó and Milan Zajac. Apart from a guided tour of the Zamość Old Town, post conference excursions included a visit to one of the largest Polish colonies of an endangered mammal, the spotted ground squirrel Spermophilus suslicus, in Popówka village. The second visit was organized for a loess grassland near the Czumów village (Bug river, Polish-Ukrainian border), with many endangered plant species. Next, the "Skarpa Dobużańska" nature reserve (Huczwa river valley) with numerous Orobanche lutea individuals was visited. More excursions were organized to the "Żmudź" nature reserve with a short Juniperus communis scrubland and some rare and protected orchid species, the steep slope "Horodysko" (Iłowiec village) with a Prunetum fruticosae scrubland, and "Machnowska Góra" reserve with the subendemic Carlina onopordifolia. The final excursion was organized for the limestone slopes of "Albrechtówka" hill (Męćmierz village, Vistula river valley) with Inuletum ensifoliae vegetation.

The historical place of Kulikovo field, near Tula, Russia hosted the $11^{\text {th }}$ EDGM, 5-16 June 2014. The aims of the EDGM-2014 were to acquaint participants with the diversity of steppe and dry grassland vegetation in different ecological situations, to discuss the influence of intensive anthropogenic impacts on steppe and dry grassland transformation and the means of restoration. The main theme of the conference was the ecology, transformation and restoration of steppes and semi-natural grasslands, with 29 talks and 18 posters presented for this (Volkova 2014). The EDGM was attended by 55 colleagues from 10 countries. The winners of the YIPs were Csaba Tölgyesi for the best talk, and Orsolya Valkó for the best poster presentation. Participants visited the protected areas "Srednyi Dubik" and "Tatinki", and experimental fields of steppe restoration (Kulikovo Field). Participants who took part in the post -conference excursions (10-15) June had the opportunity to get familiar with the vegetation of the southern regions of Russia: forest-steppes of the Kursk region and the steppes of the Rostov region. They saw not only dry grassland vegetation in the Upper Don but also in the lower reaches of the Don. Local experts gave detailed information about the biota of each region by the lectures and field excursions. During and after the conference the participants were involved in cultural programme and could see the living style of local people, and experience local meals, songs and dancing.

Next year, it was Mainz (Germany) which hosted the $12^{\text {th }}$ EDGM, 22-27 May 2015. The main topic was "Population Biology and Community Ecology of Dry Grasslands and Dry Grassland Species" and the EDGM was attended by 50 par- ticipants from 15 countries (Becker \& Becker 2015). Twenty-three talks were given and 18 posters were presented. The invited speaker Joachim W. Kadereit (Mainz) presented the "Biogeography of Rhine Gorge orophytes" and Martin Diekmann (Bremen) presented the "Long-term changes in the vegetation of dry calcareous grasslands evidence from community and population ecology". For YIPs, the two best oral presentations were given by Eleonora Giarrizzo and Lisa Thill. Best poster presentations were those of Dávid D. Nagy and Jianshuang Wu. During the conference the participants were involved in a cultural programme in the historic part of Mainz. A one half-day excursion to the dry grassland replica sites of the Botanic Garden was organised and another to the original Mainz Sand area where participants visited the westernmost dry continental sand grasslands of Koelerion glaucae and stands of the Festucion valesiacae on sandy soil. The oneday excursion to Rhine-Hesse (the Martinsberg and Höll sites near Siefersheim, and the Mühlberg and Horn sites near Neu-Bamberg) offered the opportunity to visit dry grasslands and heathlands on volcanic substrata. Finally, an excursion led to the Middle Rhine Valley with slopes covered by xerothermic vegetation complexes containing dry grasslands and Acer monspessulanum forests.

\section{The European Grassland Conferences (EGCs, 2016-)}

\section{(Plate 3)}

In summer 2015 the EDGG decided to expand its geographic scope to cover all Palaearctic grasslands and not be restricted to European ones. The name of the organization changed to Eurasian Dry Grassland Group, while the name of its annual meetings (EDGM) changed to Eurasian Grassland Conferences (EGC), in order to indicate a wider coverage (from meeting to conference, and from dry grasslands to all grasslands).

The $13^{\text {th }}$ EGC was organized in Sighisoara, Romania, 20-24 September 2016, under the main theme: "Management and Conservation of Semi-Natural Grasslands: from Theory to Practice". The EGC was attended by 85 participants from 25 countries, who listened to 26 talks and saw 32 posters (Sutcliffe et al. 2016). For the first time, the EDGG organized three optional technical workshops during its conference. The first one was about "Scientific writing" and run by Jürgen Dengler. The workshop focused on writing clear, precise and engaging scientific texts in English for publication in high impact factor international journals. The second workshop named as "Reflecting ecology in policy" and facilitated by experts in agri-environmental policy from European Forum for Nature Conservation and Pastoralism (EFNCP) (Jabier Ruiz Mirazo, Caitriona Maher) and Institute for European Environmental Policy (IEEP) (Clunie Keenleyside). The objective was to jointly analyze several biodiversity-related measures in the Common Agricultural Policy. The third workshop for "Establishing and Maintaining National Grassland Databases" was facilitated by Kiril Vassilev. A keynote talk was given from Jörn Fischer ("Integration by Place, Case and Process: Transdisciplinary 

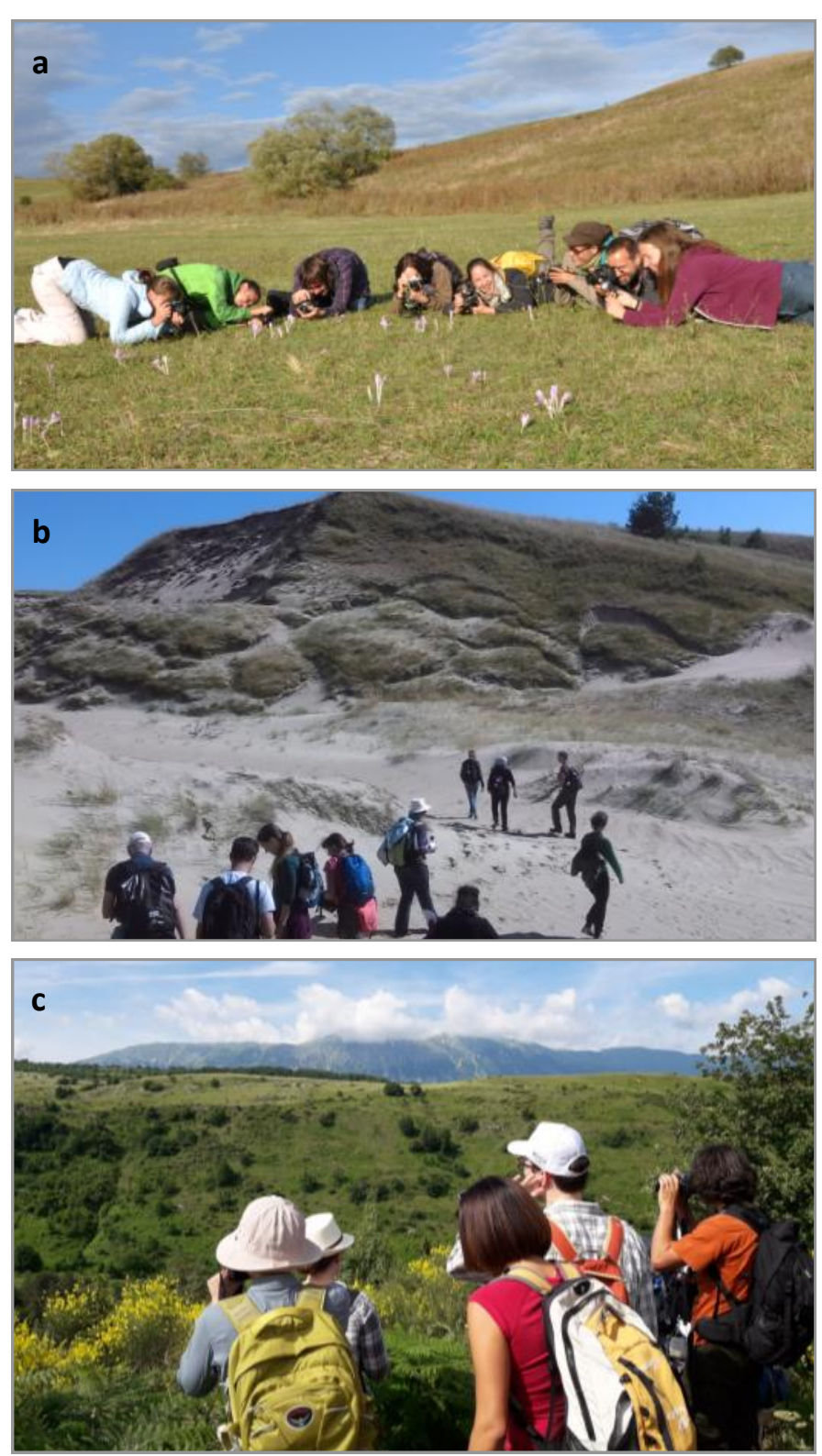

Plate 3. The Eurasian Grassland Conferences (EGC, 20162018): (a) the 13th EGC in Sighisoara, Romania (2016), (b) the 14th EGC in Riga (Latvia) - Western Lithuania (2017), (c) the 15th EGC in Sulmona, Italy (2018).

Photos: A. Csecserits (a), M. Vrahnakis (b, c).

Sustainability Science in Transylvania"). A second keynote talk was given by Cristina Craioveanu together with László Rákosy which focused on the evolution of grasslands in Transylvania and their present-day value and conservation, and how research can contribute to this. YIPs were given to Csaba Tölgyesi, Orsolya Valkó, Tsvetelina Terziyska, Szilvia Raócz, Ágnes Balázsi and Eugen Görzen. The midconference excursion was organized to the High Nature Value grasslands in the hilly Târnava Mare landscape near Sighişoara and the post-conference one to the Mountain hay meadows in the Miercurea Ciuc (Csíkszereda) area, where grassland-related activities such as meadow scything took place.
The "Semi-Natural Grasslands across Borders" was the moto of the $14^{\text {th }}$ EGC (4-11 July, 2017) shared, for the first time in the EDGG's conferences, between two countries: in Riga, Latvia, for hall sessions, and in western Lithuania for post-conference excursion. The conference placed emphasis on cases in which grassland ecosystems are shared between man-made and natural geographical, political and ecological borders. The EGC was attended by 92 colleagues from 19 countries, who took part in 23 oral and 20 poster presentations (Rūsina et al. 2017). Two optional workshops were held and led by Didzis Elferts; the first was to introduce the $\mathrm{R}$ for statistical analysis, and the second to introduce the ggplot2 graphical system. A keynote talk was given by Irina Herzon on the most recent policy developments of relevance, including the reformed CAP in 2013, and concluded that conservation policy needs to perceive semi-natural grasslands as socio-ecological systems. In her keynote talk, Aveliina Helm highlighted the research results from ten separate regions in central and northern Europe to identify regions where an extinction debt has already been paid and where it still remains to be settled, and further discussed the possible effects of landscapescale restoration activities in maintaining grassland species diversity and related ecosystem services. The winners for the YIPs were Philipp Kirschner, Kristina Plenk and Alina Baranova for best oral presentations, and Iwona Dembicz, Kristina Plenk and Yulia Rozenblit for best poster presentations. Participants of the pre-conference excursion visited the Eastern Baltic semi-natural grasslands of the Daugava River Valley. The second day was devoted to the Dviete River Valley with extensive floodplain grasslands with rare species. Participants of the mid-conference excursion visited the Abava River Valley with an exceptional calcareous dry grassland diversity, at least for Latvia. The post-conference excursion took place on the Curonian Spit and the Nemunas River Valley in western Lithuania. Participants observed the diversity of the coastal sand vegetation including sandy beaches, coastal foredune ridges, sea sand plain/palves, and the Great Dune Ridge, with shifting and fixed dunes. The Nemunas - the largest Lithuanian river floodplains - offered the diversity of the floodplain vegetation including swamp and fen vegetation, managed grasslands of different floodplain ecological belts and dry grasslands of riverine dunes.

The 15 th EGC was organized from $4^{\text {th }}$ to $8^{\text {th }}$ June 2018 in the town of Sulmona in the center Apennines in the Majella National Park, Italy. The main theme of the conference was "Cooperating for grasslands: from habitat interpretation to conservation measures" and the aim was to address the main grassland conservation issues by establishing a basis for cooperation projects within the framework of the EDGG. Fifty-nine colleagues from 18 countries attended 27 oral and 16 poster presentations (Burrascano et al. 2018). A keynote lecture was given for carabid beetle assemblages in natural and seminatural grasslands of Italy by Pietro Brandmayr. The conference started with a workshop on the main EU funding schemes related to grassland conservation (Interreg Europe and LIFE+). Another work- 
shop on effective writing for international peer-reviewed journals was led by Jurgen Dengler. There was also a workshop on the Natura 2000 Biogeographical Process; almost 50 experts participated in the workshop in the last session of the EGC. The results from the workshop will be used to support the Road Map for the Mediterranean biogeographical region, and because they are related to recurring problems also in other biogeographic regions. The best two oral presentations were those of Ludovica Oddi and Eugen Görzen, and the best two poster presentations were those of Anna Theresa Lehmair and Sven Rubanschi. The mid-conference trip participants visited different types of regionally typical grasslands, from those dominated by annual species at about $800 \mathrm{~m}$ a.s.l. to those in contact with the subalpine Pinus mugo formations. The second excursion gave the participants the possibility of enjoying one of the widest and richest grassland slopes in the $\mathrm{Na}$ tional Park and to perform a sample according to the standardized GrassPlot protocol.

Last EDGG conference, 16th EGC, was held in Austria and Slovenia, with Graz as conference venue, 29 May - 5 June 2019. Detailed report on this conference will be published in one of the next issues of Palaearctic Grasslands.

\section{Conclusions}

The annual conferences of the EDGG are the major tool for promoting the objectives of the EDGG. Every conference, especially after the official formation of the EDGG (2008), resulted in a significant expansion of EDGG as is reflected in the increase of its membership volume. The conference is a well-established fixture between members of the EDGG and year by year is becoming better known amongst plant ecologists, botanists and phytosociologists. Major challenges in the coming years for the Executive Committee of the EDGG are to expand the conference interests in underrepresented topics, like animal ecology, soil science, grassland management and to extend the conference locations to western Europe, north Africa and Asia.

\section{Acknowledgments}

My warm thanks to the members of the Executive Committee of the EDGG and especially to Monika Janisova, and Didem Ambarli, who as deputy coordinators supported me in the organization of the EGCs. I also like to thank our supporting organizations IAVS (for travel grants) and Wiley (for Young Investigator Prizes). Finally, all those members of the Local Organizing Committees and many friends who did their best to organize our splendid conferences.

\section{References}

Anon. 2009. 6th European Dry Grassland Meeting in Halle (Saale), Germany 31 August - 3 September 2009. Bulletin of the European Dry Grassland Group 4: 3-6.

Becker, U. \& Becker, T. 2015. The 12th European Dry Grassland Meeting in Mainz 2015. Bulletin of the Eurasian Dry Grassland Group 27: 6-10.

Burrascano, S., Ciaschetti, G., Vrahnakis, M. \& Dengler, J. 2018. Report on the 15th Eurasian Grassland Conference in Sulmona, Italy. Palaearctic Grasslands 38: 12-17.

Chmielewski, P. 2013. The 10th European Dry Grassland Meeting in Zamosc, Poland (24-31 May 2013). Bulletin of the European Dry Grassland Group 19-20: 14-16.

Dolnik, C. 2008. The 5th annual meeting of the AG Trockenrasen and the 1st meeting of the Working Group on Dry Grasslands in the Nordic and Baltic Region. Bulletin of the European Dry Grassland Group 1: 8-9.

Janišová, M., Škodová, I. \& Hegedušová, K. 2010. 7th European Dry Grassland Meeting. Bulletin of the European Dry Grassland Group 7: 4-6.

Kuzemko, A. 2011. 8th European Dry Grassland Meeting. Bulletin of the European Dry Grassland Group 11: 4-8.

Rūsina, S., Gustiṇa, L., Sniedze-Kretalova, R. \& Rašomavičius, V. 2017. Report from the 14th Eurasian Grassland Conference, 411 July 2017, in Riga, Latvia and western Lithuania. Bulletin of the Eurasian Dry Grassland Group 35: 11-19.

Sutcliffe, L., Akeroyd, J., Gherghiceanu, L., Mountford, O., Page, N. \& Ruprecht, E. 2016. Post-conference report for the 13th Eurasian Grassland Conference 2016 in Sighisoara, Romania. Bulletin of the Eurasian Dry Grassland Group 32: 3-7.

Volkova, E. 2014. The 11th European Dry Grassland Meeting in Tula 2014. Bulletin of the European Dry Grassland Group 23: 12-14.

Vrahnakis, M. 2012. The 9th European Dry Grassland Meeting in Greece (19-23 May 2012). Bulletin of the European Dry Grassland Group 16: 7-13.

Vrahnakis, M. 2015. Organizing a Eurasian Dry Grassland Conference. A user's guide. URL: https://edgg.org/pdf/ How to_organize_a_EDGM_26_04_2015.pdf.

Vrahnakis, M., Kyriazopoulos, A.P., Chouvardas, D. \& Fotiadis, G. (eds.). 2013. Dry grasslands of Europe: grazing and ecosystem services. Proceedings of 9th European Dry Grassland Meeting (EDGM) Prespa, Greece, 19-23 May 2012. Hellenic Range and Pasture Society (HERPAS), Thessaloniki, GR. 


\title{
Ski runs as an alternative habitat for threatened grassland plant species in Japan
}

\author{
Yuki A. Yaida ${ }^{1 *}$, Takuma Nagai ${ }^{1}$, Kazuya Oguro ${ }^{2}$, Koki R. Katsuhara ${ }^{1} \odot$, Kei Uchida ${ }^{3} \odot$, Tanaka Kenta ${ }^{2} \odot \&$ \\ Atushi Ushimaru ${ }^{1}{ }^{\circ}$
}

\begin{abstract}
${ }^{1}$ Graduate School of Human Development and Environment, Kobe University, 3-11 Tsurukabuto, Kobe 657-8501, Japan; yuki.yaida@gmail.com (Y.A. Yaida), t.nagai0246@gmail.com (T. Nagai), k.katsuhara0228@gmail.com (K.R. Katsuhara), ushimaru@kobe-u.ac.jp (A. Ushimaru)

${ }^{2}$ Sugadaira Research Station, Mountain Science Center, University of Tsukuba, Sugadaira-kogen, Ueda 386-2204, Japan; k.oguro.h3@gmail.com (K. Oguro), kenta@sugadaira.tsukuba.ac.jp (T. Kenta)
\end{abstract}

\begin{abstract}
${ }^{3}$ Graduate School of Environment and Information Sciences, Yokohama National Univarsity, 79-7 Tokiwa-dai, Yokohama 240-8501, Japan, k.uchida023@gmail.com
\end{abstract}

*) Corresponding author: yuki.yaida@gmail.com

Palaearctic Grasslands 42 (2019): 16-22

Abstract: Land use changes have been major drivers of global biodiversity declines during the last century. Although ski resort developments generally cause biodiversity loss in mountainous grassland and forest ecosystems of East Asia, Europe and North America, they can sustainably harbor grassland species which have largely been lost via various land use changes during the last decades. In this study, we surveyed distributions of native endangered and threatened grassland plant species in ski run grasslands of Sugadaira area in the central Japan. We found that ski run grasslands converted from old pastures were habitats of eight native endangered and threatened grassland species, which have been drastically declining in recent decades. Richness of these plant species increased with direct sunlight duration and soil pH: more open ski runs and those with soil pH of approx. 5.0-5.8 exhibited higher richness. According to our results, we discussed the potential of ski runs as an alternative habitat type of native endangered and threatened grassland plants.

Keywords: endangered plant species; Japan; semi-natural grassland; ski run; soil pH; sunlight duration.

Nomenclature: Yonekura \& Kajita (2003) for vascular plants .

Abbreviations: $\mathrm{EN}=$ endangered; $\mathrm{NT}=$ near threatened; $\mathrm{VU}=$ vulnerable.

Submitted: 11 February 2019; first decision: 1 April 2019; accepted: 4 May 2019

Scientific Editor: James Moran

Linguistic Editor: James Moran

\section{Introduction}

Land use changes have been major drivers of global biodiversity loss during the last century (Sala et al. 2000; Gerstner et al. 2014). Negative effects of land use changes on biodiversity and the underlying mechanisms have been intensively examined in both natural and semi-natural ecosystems worldwide (Butchart et al. 2010; Newbold et al. 2015). Grassland biodiversity in the Palaearctic realm has also been threatened by several types of land use changes (Dengler et al. 2014; Wesche et al. 2016), among which grassland abandonment and conversion to arable lands have exerted a prevailing threat to grassland biodiversity in this region (Török \& Dengler 2018).

Ski resort development is a typical land use change, which has negative impacts on biodiversity of mountainous grassland ecosystems in East Asia, Europe and North America (Tsuyuzaki 1994; Wipf et al. 2005; Rolando et al. 2007; Burt \& Rice 2009; Roux-Fouillet et al. 2011). In ski runs, machine grading and artificial snow application are known to increase bare ground coverage and/or to change soil moisture and nutrient conditions and therefore influence plant diversity and composition (Tsuyuzaki 1995; Tsuyuzaki
2002; Rolando et al. 2007; Burt \& Rice 2009; Roux-Fouillet et al. 2011). Soil erosion caused by machine grading leads to low water content and reduction in soil depth (Tsuyuzaki 1990; Watson 1985). After grading, introduced vegetation cover to preventing soil erosion would promote high dominance of alien plant species at the pioneer vegetation stage (Tsuyuzaki 1995; Tsuyuzaki 2002).

Although ski resort developments generally degrade biodiversity in the alpine zones, they have the potential to maintain semi-natural grassland biodiversity which has largely been lost via various land use changes during the last decades below the timberline in the Palaearctic region (Rolando et al. 2007; Ushimaru et al. 2018). This is because typical mowing management once a year maintains seminatural grassland conditions on ski runs. However, the potential of ski run grasslands as an alternative habitat for native grassland plants has not been examined in Japan.

In this study, we surveyed the distribution of native endangered and threatened grassland plant species in ski run grasslands in Sugadaira area, Nagano prefecture in the central Japan (Fig. 1). In the study area, old pastures conversion to ski runs in the early $20^{\text {th }}$ has maintained grass- 
land conditions continuously for more than 100 years on the slopes. Ski runs are typically surrounded by secondary forests and Larix kaempferi plantations which have established on abandoned pastures (Fig. 1). We examined richness of native endangered and threatened grassland plant species on ski run grasslands and how distributions of these species were related to vegetation and environmental factors. According to our results, we discuss the potential of ski run grasslands as alternative habitat for semi-natural grassland biodiversity.

\section{Study area}

The study was conducted in 13 ski runs in Sugadaira- and Minenohara-plateau ski resorts in the Sugadaira area, Nagano Prefecture, Japan (Fig. 1; $36.512^{\circ}-36.561^{\circ} \mathrm{N}$, $138.304^{\circ}-138.360^{\circ} \mathrm{E}, 1325-1510 \mathrm{~m}$ a.s.l.). In the study area, the mean annual temperature was $6.5^{\circ} \mathrm{C}$, with a minimum monthly average of $-6.2^{\circ} \mathrm{C}$ in January, and a maximum monthly average of $19.4^{\circ} \mathrm{C}$ in July. The mean annual precipitation was $1197.4 \mathrm{~mm}$ during 1986-2015. These meteorological data were recorded by nearby automated meteorological data acquisition system $\left(36.532^{\circ} \mathrm{N}\right.$, $138.325^{\circ} \mathrm{E}, 1253 \mathrm{~m}$ a.s.l.) by the Japanese Meteorological Agency.

All study ski runs are distributed in cool temperate zone, where the climax vegetation are broad-leaved deciduous forests. For all the study ski runs, semi-natural grassland conditions have been maintained by annual mowing (mowing once in September) as a typical ski run maintenance. Cut plant materials were left in situ for all the runs every year. Wild vertebrate herbivore grazing seldom oc-
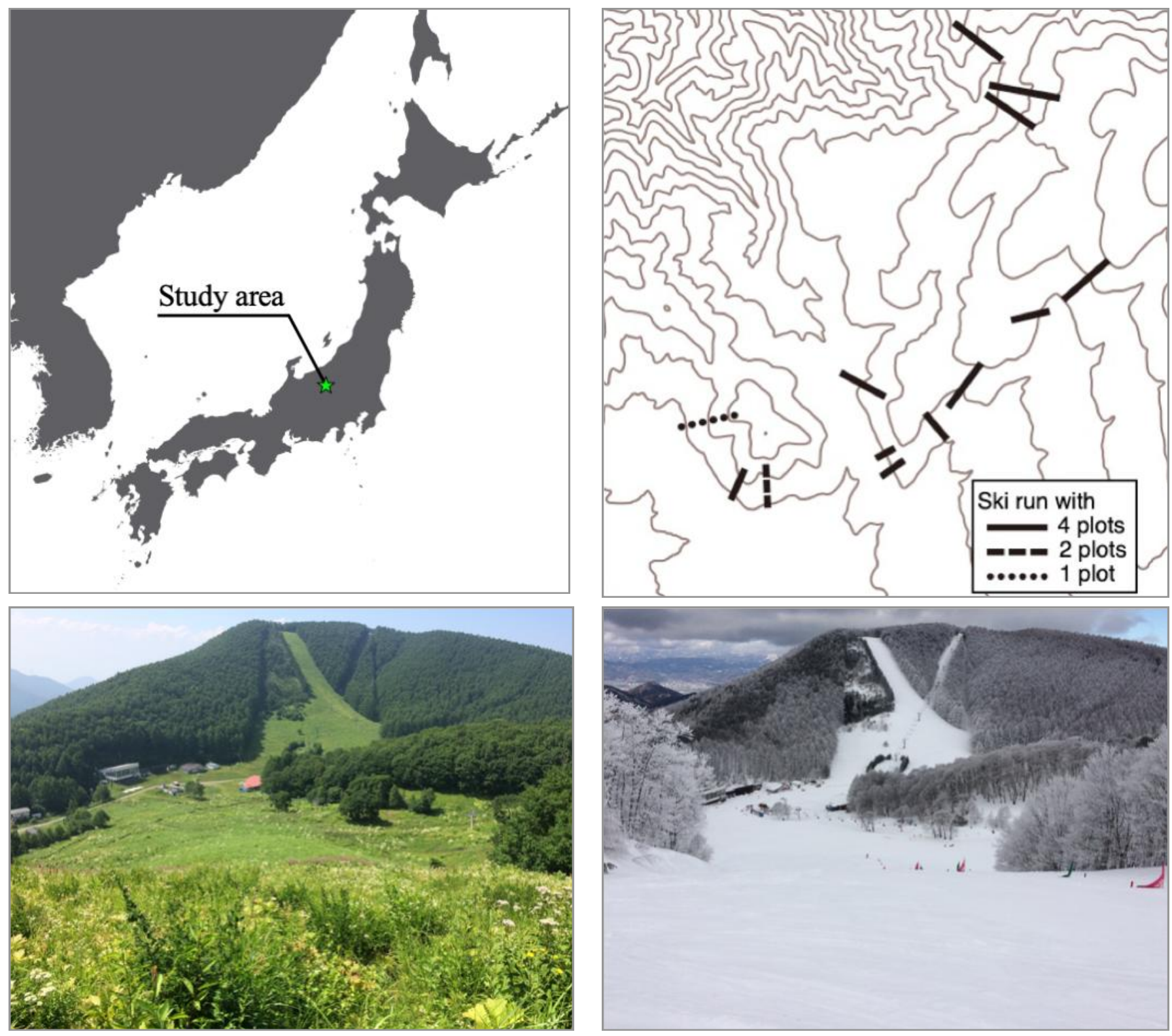

Fig. 1. Location of study area (Sugadaira area), Nagano prefecture, Japan (a), distribution of study runs and plots with 50 $\mathrm{m}$ contour line (b) and the study ski runs are indicated by bold, broken and dotted lines (the numbers of plots were 4,2 and 1, respectively). Photos of a ski run in summer (c) and winter (d) are shown. 
Table 1. The mean and standard deviation (SD) of environmental variables in the study plots.

\begin{tabular}{ccccccc}
\hline & $\begin{array}{c}\text { Vegetation } \\
\text { height }(\mathbf{c m})\end{array}$ & $\begin{array}{c}\text { Aboveground } \\
\text { biomass }(\mathbf{g})\end{array}$ & $\begin{array}{c}\text { Soil water con- } \\
\text { tent (\%) }\end{array}$ & Soil pH & $\begin{array}{c}\text { Slope angle } \\
\left.\mathbf{(}^{\circ}\right)\end{array}$ & $\begin{array}{c}\text { Sunlight duration } \\
\text { (min) }\end{array}$ \\
\cline { 2 - 7 } Mean & 75.54 & 16.97 & 39.75 & 5.177 & 18.66 & 760.1 \\
\pm SD & \pm 32.98 & \pm 9.79 & \pm 8.43 & \pm 0.271 & \pm 6.88 & \pm 109.9 \\
\hline
\end{tabular}

curred in the ski runs, although Japanese deer have invaded the study area very recently.

\section{Vegetation survey}

We set four $2 \times 10 \mathrm{~m}\left(20 \mathrm{~m}^{2}\right)$ belt plots on each of the 13 ski runs. Plots were positioned at the center and the edge of upper and lower positions of each run (Fig. 1). The width of study ski runs ranged from 26 to $167 \mathrm{~m}$ (mean \pm SD: $78 \pm$ $3 \mathrm{~m}$ ). We focused on ski run areas directly converted from old pasture and as such areas were of limited distribution in two runs, we used data from only 1 or 2 plots on these runs (Fig. 1). Locations of old pasture were checked using past aerial photographs taken in 1947, 1965, 1973, 1975, 1991 (Geographical Information Authority of Japan, GIAJ, http://mapps.gsi.go.jp/maplibSearch.do\#1). We thus set a total of 47 plots on the 13 runs.

We conducted vegetation surveys twice in the late June and the early August for each plot in 2015. During the survey of each plot, we recorded the presence of all native endangered and threatened grassland plant species listed in the National Red list (Ministry of the Environment of Japan). To define "grassland" species, we referred to Wild Flowers of Japan Herbaceous Plants I - III (Satake et al. 1981). For the following analyses, we pooled two survey data sets and counted the richness of the red list species in each plot.

\section{Vegetation and environmental factors}

We recorded vegetation height, aboveground biomass, soil water content, soil $\mathrm{pH}$, sunlight duration, and slope angle for each plot in August 2015 (Table 1). At five points within each plot $(1,3,5,7$ and $9 \mathrm{~m}$ from the edge of the plot on the center line), we measured the height (in $\mathrm{cm}$ ) of the highest aboveground plant part within a $10-\mathrm{cm}$ radius at each point and averaged them as vegetation height per plot for the following analyses. To measure aboveground biomass, we clipped all of the above-ground living vascular plant material from two additional $0.25 \times 0.25 \mathrm{~m}$ subplots just beside each plot, dried the material at $70^{\circ} \mathrm{C}$ for $72 \mathrm{~h}$, and weighted the dry biomass for each subplot. We used the mean aboveground biomass per plot for the analyses.

At the same time of biomass sampling, we collected soil samples at a depth of $0-5 \mathrm{~cm}$ using a cylindrical soil corer with a diameter of $5-\mathrm{cm}$ and a height of $5-\mathrm{cm}$ (ca. $100 \mathrm{~cm}^{3}$ ) from the two subplots. For each plot, the two fresh soil samples were mixed then weighted, dried at $70{ }^{\circ} \mathrm{C}$ for 72 $h$, and weighted again. Soil water content (SWC in \%) was calculated as follows (Nagata \& Ushimaru 2016):

$$
S W C=\frac{\text { fresh soil weight }(g)-\text { dry soil weight }(g)}{\text { fresh soil weight }(g)} \times 100
$$

In addition, soil $\mathrm{pH}$ was measured by mixed and dried soil samples, in a 2:5 (w:w) dry soil:distilled water mixture using a HI 991221 Direct Soil pH measurement instrument (HANNA Instruments, Smithfeild, RI, US). We took a hemispherical photograph at 1-m above ground height of the center of each plot in late August, when the weather was cloudy. For each site, we calculated direct sunlight duration at the summer solstice (in minutes; hereafter direct sunlight duration) as an index of light conditions during the growing season using a hemispherical photograph analysis program, CanopOn 2 (http://takenaka-akio.org/etc) canopon2/).

\section{Statistical analyses}

To examine the effects of vegetation and environmental factors on endangered grassland species richness, we constructed a generalized linear model (GLM) with Poisson distribution and log-link function in which vegetation height, aboveground biomass, soil water content, soil $\mathrm{pH}$, sunlight duration, and slope angle were incorporated as the explanatory variables, the number of endangered and threatened species per plot was incorporated as the response variable. Because vegetation height was highly correlated with the aboveground biomass in our data set (Pearson correlation coefficient: $r=0.578, P<0.001, n=$ 47) and the variance inflation factor value (VIF; the value = 2.6) of vegetation height in the full model was higher than those of other variables and over 2.0 (Brauner \& Shacham 1998), we reconstructed a GLM without vegetation height as the explanatory variable.

Because a single threatened species, Platycodon grandiflorus was frequently observed in the study plots, we also examined the effects of vegetation height, aboveground biomass, soil $\mathrm{pH}$, soil water content, slope angle, and sunlight duration on the presence/absence of the species in each plot using a GLM with binomial distribution and logistic-link function. In the model, all the variables were explanatory variables and the presence/absence $(1 / 0)$ of the species was the response variable. Because the study runs and plots were not randomly distributed within the study area, the effects of spatial autocorrelation on the analytical results should be also considered. We calculated the spatial auto-covariates from the latitude and longitude measurements of the study plots, incorporating values into each GLM, which was achieved through a simple extension of the GLM by adding a distance-weighted function of neighboring response values as the explanatory variable (Dormann et al. 2007). The significance of each explanatory variable was examined with a Wald test. For all analyses, we used the statistical software R v3.3.2 and the vegan package v2.4.1 (R core Team 2016). 
Table 2. Observed endangered and threatened species and their Red list category (The Ministry of the Environment of Japan, EN: endangered, VU: vulnerable, NT: near threatened), life form and the number of center and edge plots where the species occurred.

\begin{tabular}{|c|c|c|c|c|c|}
\hline \multirow{2}{*}{ Family } & \multirow{2}{*}{ Scientific Name } & \multirow{2}{*}{$\mathbf{R} \mathbf{L}$} & \multirow{2}{*}{ Life form } & \multicolumn{2}{|c|}{ No. of plots } \\
\hline & & & & Center & Edge \\
\hline Boraginaceae & Lithospermum erythrorhizon & EN & Perennial & 0 & 1 \\
\hline \multirow[t]{2}{*}{ Apocynaceae } & Vincetoxicum atratum & VU & Perennial & 0 & 2 \\
\hline & Vincetoxicum pycnostelma & NT & Perennial & 2 & 1 \\
\hline Plantaginaceae & Veronica onoei & VU & Perennial & 4 & 4 \\
\hline Campanulaceae & Platycodon grandiflorus & VU & Perennial & 10 & 9 \\
\hline Caprifoliaceae & Triosteum sinuatum & VU & Perennial & 1 & 1 \\
\hline Asteraceae & Tephroseris flammea subsp. glabrifolia & VU & Perennial & 3 & 0 \\
\hline Ranunculaceae & Pulsatilla cernua & VU & Perennial & 1 & 1 \\
\hline
\end{tabular}

\section{Results}

In total, we found eight endangered and threatened native grassland species in the study plots (Fig. 2 and Table 2). The GLM for their richness revealed significantly positive effects of soil $\mathrm{pH}$ and direct sunlight duration on the species richness and non-significant effects of any of the other variables (Fig. 3 and Table 3). The presence of $P$. grandiflorus increased with direct sunlight duration, whereas the other variables did not have any significant effects on the P. grandiflorus presence (Fig. 4 and Table 3).

\section{Discussion}

Eight endangered and threatened grassland species including a single EN species, Lithospermum erythrorhizon, were found in study ski run grasslands, suggesting that ski resort developments have a potential to harbor these grassland
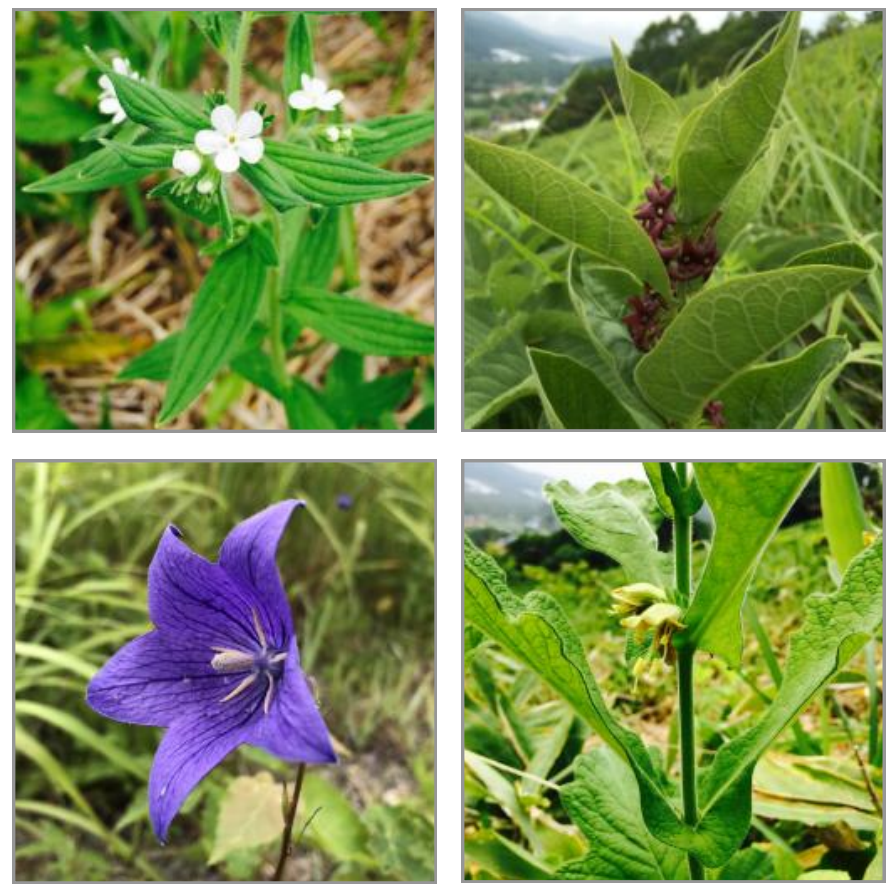

plant species of conservation importance in Japan. Since semi-natural grasslands have been declining rapidly via several types of land use change during the last century in Japan as well as in other areas in the Palaearctic realm (Dengler et al. 2014; Nagata \& Ushimaru 2016; Uchida et al. 2016; Török \& Dengler 2018; Ushimaru et al. 2018), it is valuable information that the new land use, ski run use can retain habitats for native endangered and threatened grassland plants.

Higher soil pH (c. 5.0-5.8, see Table 1) within the acid range of the study ski runs was suggested to be preferred by the study species. Rare species, including some endangered grassland species are known to have narrower ecological niches compared to common species with respect to soil biogeochemical parameters in Europe and Japan (Kleijn et al. 2008; Uematsu \& Ushimaru 2013). The unimo-
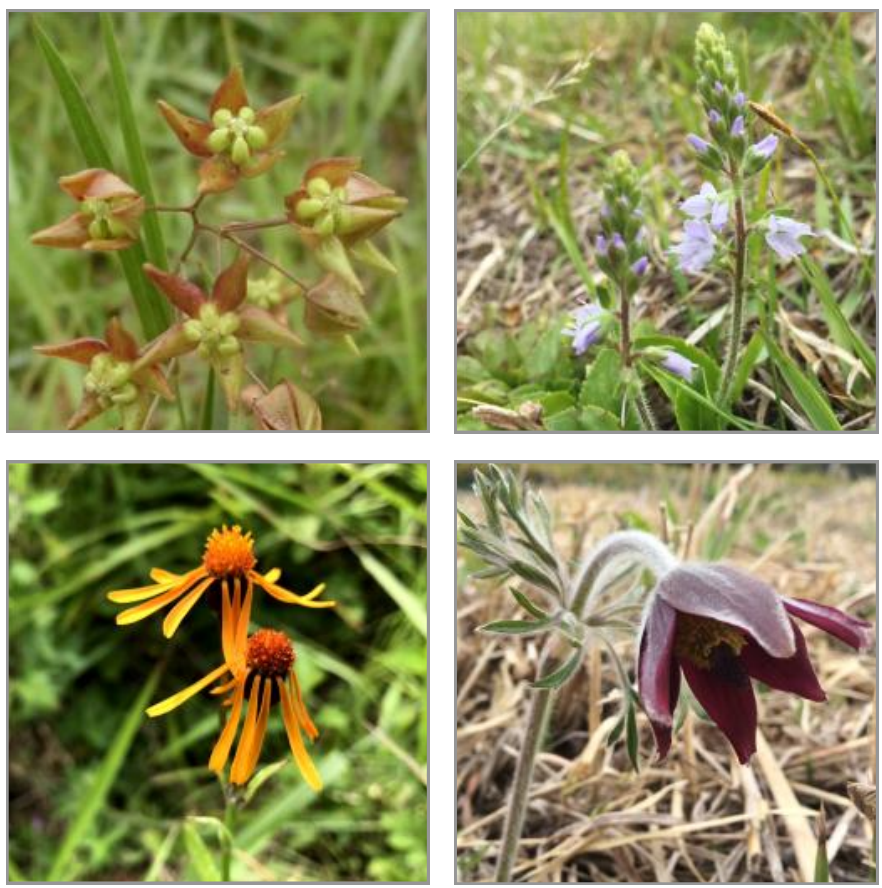

Fig. 2. Photos of native endangered and threatened grassland plants on ski run grasslands in the Sugadaira area, Nagano prefecture, Japan. Upper row from left to right: Lithospermum erythrorhizon, Vincetoxicum atratum, V. pycnostelma, Veronica onoei. Lower row from left to right: Platycodon grandiflorus, Triosteum sinuatum, Tephroseris flammea subsp. glabrifolia and Pulsatilla cernua. Photos: Y.A. Yaida \& A. Ushimaru. 


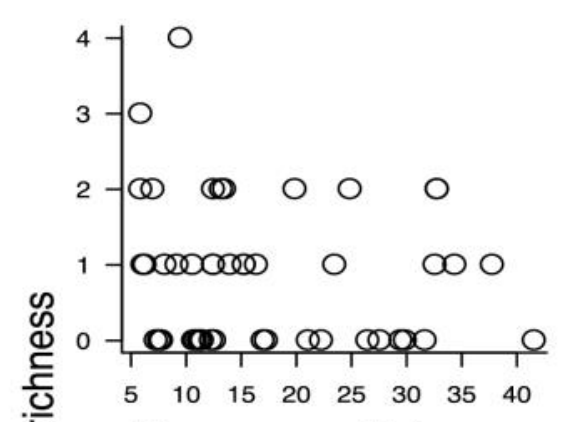

Aboveground biomass

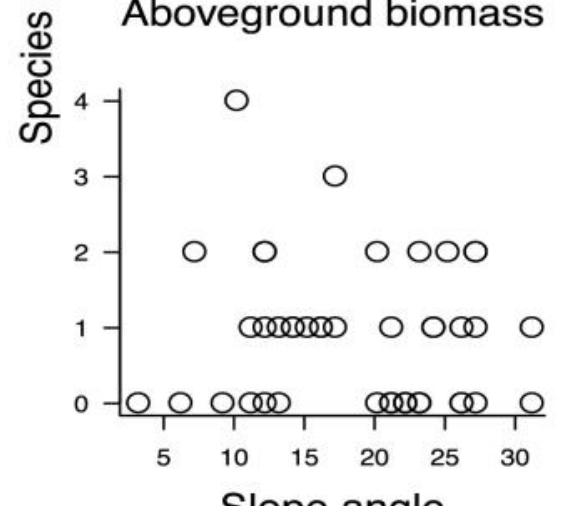

Slope angle

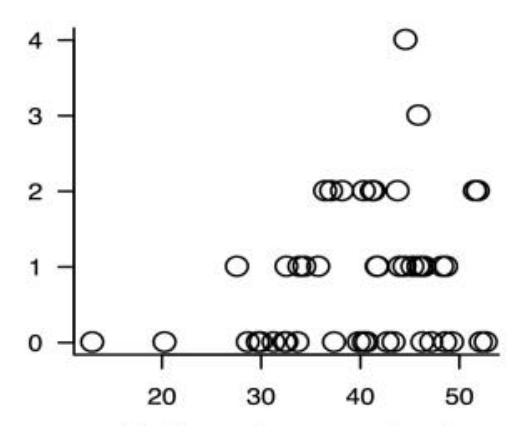

Soil water content

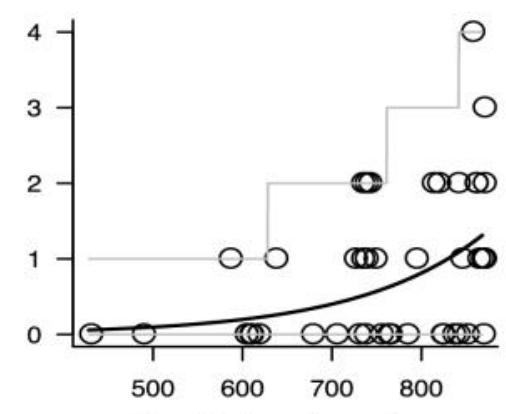

Sunlight duration

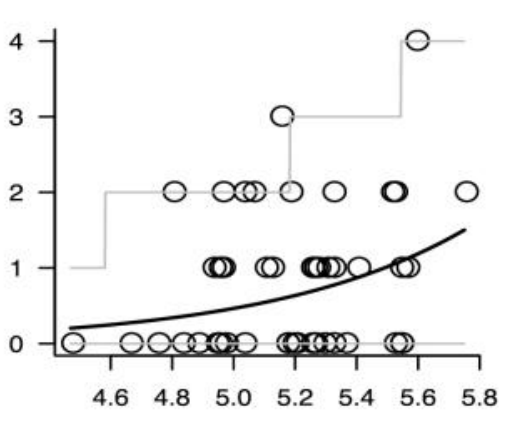

Soil $\mathrm{pH}$

Fig. 3. Relationships of native endangered and threatened grassland species richness with vegetation and environment variables. The regression lines (black) and the $\mathbf{9 5 \%}$ prediction intervals (grey) are drawn for the significant explanatory variables (GLM, Table 3). The regression line was calculated using fixed values (i.e. means) for the other explanatory variables.

Table 3. The GLM results for native endangered and threatened grassland plant richness and the presence/absence of Platycodon grandiflorus. Estimated coefficients, SEs, $z$ values and $p$ values by Wald test are shown. Variables with statistically significant effects $(p<0.05)$ are indicated in bold.

\begin{tabular}{lcccc}
\hline Explanatory variables & Estimate & SE & $\boldsymbol{z}$ & $\boldsymbol{p}(>|\mathbf{z}|)$ \\
\hline & Response variable: & native endangered and threatened grassland plant richness & \\
Intercept & $-1.418 \times 10$ & 4.359 & -3.253 & $<0.01$ \\
Aboveground biomass & $-5.251 \times 10^{-3}$ & $1.860 \times 10^{-2}$ & -0.282 & 0.778 \\
Soil water content & $2.810 \times 10^{-2}$ & $2.387 \times 10^{-2}$ & 1.177 & 0.239 \\
Soil pH & $\mathbf{1 . 5 6 2}$ & $6.645 \times 10^{-1}$ & $\mathbf{2 . 3 5 2}$ & $<0.05$ \\
Slope angle & $-2.786 \times 10^{-2}$ & $2.811 \times 10^{-2}$ & -0.991 & 0.322 \\
Sunlight duration & $\mathbf{7 . 0 4 3 \times 1 0 ^ { - 3 }}$ & $\mathbf{2 . 5 0 5 \times 1 0 ^ { - 3 }}$ & $\mathbf{2 . 8 1 1}$ & $<0.01$ \\
Spatial auto-covariance & $-2.537 \times 10^{-5}$ & $3.590 \times 10^{-5}$ & -0.707 & 0.480 \\
& \multicolumn{1}{c}{ Response variable: the presence/absence of P. grandiflorus } & & \\
Intercept & $-2.699 \times 10$ & $1.115 \times 10$ & -2.420 & $<0.05$ \\
Aboveground biomass & $1.502 \times 10^{-2}$ & $4.418 \times 10^{-2}$ & 0.340 & 0.734 \\
Soil water content & $4.374 \times 10^{-2}$ & $5.166 \times 10^{-2}$ & 0.847 & 0.397 \\
Soil pH & 2.716 & 1.665 & 1.631 & 0.103 \\
Slope angle & $6.008 \times 10^{-3}$ & $6.046 \times 10^{-2}$ & 0.099 & 0.921 \\
Sunlight duration & $\mathbf{1 . 2 8 2 \times 1 0 ^ { - 2 }}$ & $\mathbf{5 . 4 1 9 \times 1 0 ^ { - 3 }}$ & $\mathbf{2 . 3 6 6}$ & $<0.05$ \\
Spatial auto-covariance & $8.017 \times 10^{-5}$ & $1.022 \times 10^{-4}$ & 0.784 & 0.433 \\
\hline
\end{tabular}




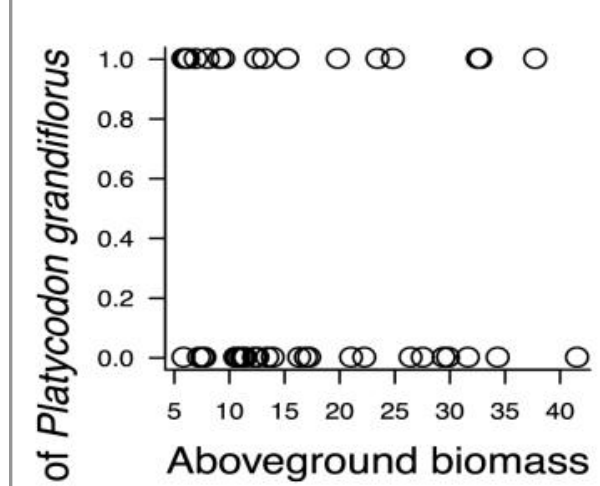

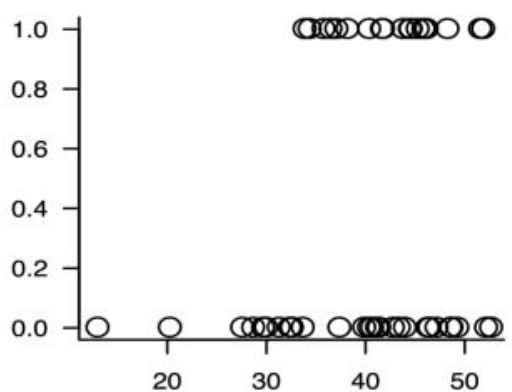

Soil water content

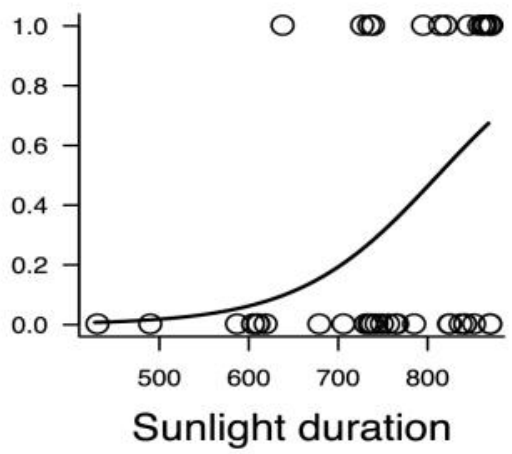

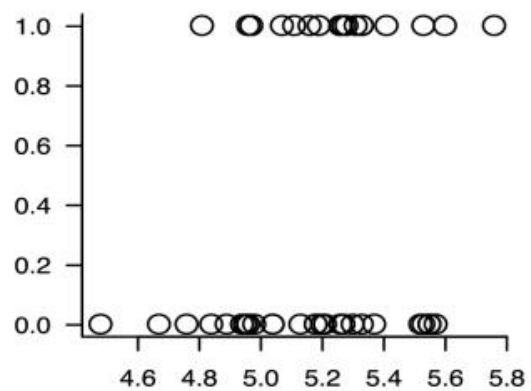

Soil $\mathrm{pH}$

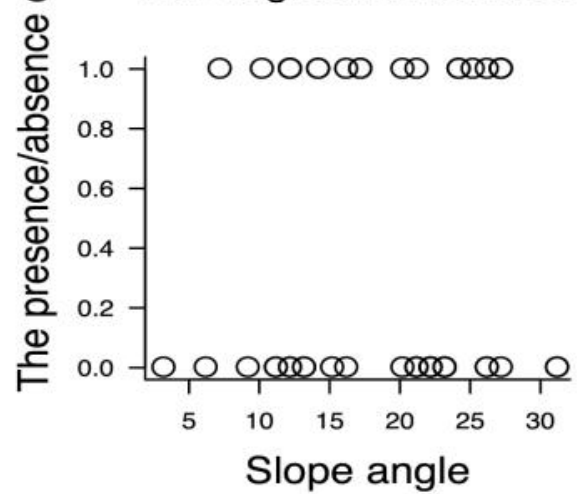

Fig. 4. Relationship between the Platycodon grandiflorus presence/absence (1/0) and vegetation and environmental variables. The regression line for the significant explanatory variable (GLM, Table 3 ) is drawn while the other explanatory variables are fixed as mean values.

dal relationship between soil $\mathrm{pH}$ and rare species richness was reported in Japanese hay meadows, such that plots with soil $\mathrm{pH}$ of c. 4.7-5.7 had higher rare species richness than those with lower and higher soil pH (Nagata \& Ushimaru 2016). The $\mathrm{pH}$ range with higher endangered and threatened species richness in this study is consistent with the $\mathrm{pH}$ range of the previous study (Nagata \& Ushimaru 2016).

The endangered and threatened grassland species richness and the Platycodon grandiflorus presence significantly increased with the sunlight duration on ski runs, indicating that more open grasslands without neighboring forests were preferred by the species. The findings suggest that endangered and threatened grassland plants may require sufficient light conditions. Meanwhile, the species richness was influenced neither by the vegetation height nor the aboveground biomass, although endangered and threatened species are often distributed in habitats with low aboveground biomass and vegetation height in Europe and Japan (Venterink et al. 2003; Wassen et al. 2005; Nagata \& Ushimaru 2016). The annual mowing management might maintain enough low vegetation height and aboveground biomass for such species everywhere in the study ski runs whereas the establishments of secondary forests and conifer plantations might cause habitat degradation for the endangered and threatened grassland species via reducing direct sunlight.
Our findings give important insights to conservation planning for semi-natural grassland biodiversity in Japan. First, to maintain ski runs like semi-natural grasslands is effective to provide habitats for endangered and threatened grassland species. Ski runs are known to function as a habitat of an endangered butterfly species, Melitaea ambigua as well (Nakahama et al. 2018). Second, open and wide ski runs with soil pH of c. 5.0-5.8 would be more ideal for conserving endangered and threatened grassland species. Therefore, abandonment and narrowing of ski runs and artificial snow (ammonium sulfate) application and surface soil removal by machine grading, both of which will change soil properties (c.f. Watson 1985; Tsuyuzaki 1990; Tatemoto \& Nakamura 1998; Roux-Fouillet et al. 2011), should be avoided. Unfortunately, some ski runs and their managements have been abandoned during the last decades due to economic reasons (Nakamura 1999) whereas other runs have been more intensively managed with machine grading and snow application (A. Ushimaru personal observation). We should inform resort companies, national and local governments, local residents, conservationists and researchers that ski runs have functioned as habitats for endangered grassland plants by providing more open grassland conditions for more than 70 years. Although this study concentrated on endangered and threatened plant species which were distributed in low densities, diversity and composition of whole grassland plant and animal species on ski runs should be examined to clarify the potential 
of ski runs as a new habitat type for the whole seminatural grassland community in future.

\section{Author contributions}

Y.A.Y., T.K. and A.U. planned the research. All authors conducted field works. Y.A.Y. and A.U. conducted statistical analyses and wrote the first manuscript and all authors critically revised the manuscript.

\section{Acknowledgements}

We thank Y. Sakata, N. Nakahama, S. Matsuhisa, K. Aoki, K. Murakami, K. Takashima for their field assistance and A. Nikkeshi and M. K. Hiraiwa for their suggestions on statistical analyses. We are grateful to all of the Sugadaira-kogen and Minenohara-kogen snow resort owners and managers for allowing our fieldworks.

\section{References}

Brauner, N. \& Shacham, M. 1998. Role of range and precision of the independent variable in regression of data. AIChE Journal 44: 603-611.

Burt, J.W. \& Rice, K.J. 2009. Not all ski slopes are created equal: disturbance intensity affects ecosystem properties. Ecological Applications 19: 2242-2253.

Butchart, S.H.M., Walpole, M., Collen, B., Strien, A. van, Scharlemann, J.P.W., Almond, R.E.A., Baillie, J.E.M., Bomhard, B., Brown, C. \& Watson, R. 2010. Global biodiversity: indicators of recent declines. Science 328: 1164-1168.

Dengler, J., Janišová, M., Török, P. \& Wellstein, C. 2014. Biodiversity of Palaearctic grasslands: a synthesis. Agriculture, Ecosystems \& Environment 182: 1-14.

Dormann, C.F., McPherson, J.M., Araújo, M.B., Bivand, R., Bolliger, J., Carl, G., Davies, R.G., Hirzel, A., Jetz, W., (...) \& Wilson, R. 2007. Methods to account for spatial autocorrelation in the analysis of species distributional data: a review. Ecography 30: 609-628.

Gerstner, K., Dormann, C.F., Stein, A., Manceur, A.M. \& Seppelt, R. 2014. Effects of land use on plant diversity - a global metaanalysis. Journal of Applied Ecology 51: 1690-1700.

Kleijn, D., Bekker, R.M., Bobbink, R., Graaf, M.C.C.D. \& Roelofs, J.G.M. 2008. In search for key biogeochemical factors affecting plant species persistence in heathland and acidic grasslands: a comparison of common and rare species. Journal of Applied Ecology 45: 680-687.

Nagata, Y.K. \& Ushimaru, A. 2016. Traditional burning and mowing practices support high grassland plant diversity by providing intermediate levels of vegetation height and soil $\mathrm{pH}$. Applied Vegetation Science 19: 567-577.

Nakahama, N., Uchida, K., Ushimaru, A. \& Isagi, Y. 2018. Historical changes in grassland area determined the demography of semi -natural grassland butterflies in Japan. Heredity 121: 155-168.

Nakamura, T. 1999. A review of scientific studies on ski areas in Japan. Japanese Journal of Ecology 49: 261-264. [In Japanese]

Newbold, T., Hudson, L.N., Hill, S.L.L., Contu, S., Lysenko, I., Senior, R.A., Börger, L., Bennett, D.J., Choimes, A. \& Purvis, A. 2015. Global effects of land use on local terrestrial biodiversity. Nature 520: 45-50.

R Core Team. 2016. R: A language and environment for statistical computing. R Foundation for Statistical Computing, Vienna, Austria. URL: https://www.R-project.org/.
Rolando, A., Caprio, E., Rinaldi, E. \& Ellena, I. 2007. The impact of high-altitude ski-runs on alpine grassland bird communities. Journal of Applied Ecology 44: 210-219.

Roux-Fouillet, P., Wipf \& S., Rixen, C. 2011. Long-term impacts of ski piste management on alpine vegetation and soils. Journal of Applied Ecology 48: 906-915.

Sala, O.E., Chapin, F.S., Armesto, J.J., Berlow, E., Bloomfield, J., Dirzo, R., Huber-Sanwald, E., Huenneke, L.F., Jackson, R.B., (...) \& Wall, D.H. 2000. Global biodiversity scenarios for the year 2100. Science 287: 1770-1774.

Satake, Y., Ohwi, J., Kitamura, S., Watari, S. \& Tominari, T. 1981. Wild Flower of Japan: Herbaceous Plants. Vols. I-III. Heibonsha, Tokyo, JP. [In Japanese]

Tatemoto, Y. \& Nakamura, T. 1998. The actual situation of using ammonium sulfate in skiing areas. Japan Outdoor Education Journal 2-1: 13-19. [In Japanese]

Török, P. \& Dengler, J. 2018. Palaearctic grasslands in transition: overarching patterns and future prospects. In: Squires, V.R., Dengler, J., Feng, H. \& Hua, L. (eds.) Glasslands of the world: diversity, management and conservation, pp. 15-26. CRC Press, Boca Raton, US.

Tsuyuzaki, S. 1990. Species composition and soil erosion on a ski area in Hokkaido, northern Japan. Environmental Management 14: 203-207.

Tsuyuzaki, S. 1994. Environmental deterioration resulting from ski -resort construction in Japan. Environmental Conservation 21: 121-125.

Tsuyuzaki, S. 1995. Ski slope vegetation in central Honshu, Japan. Environmental Management 19: 773-773.

Tsuyuzaki, S. 2002. Vegetation development patterns on skislopes in lowland Hokkaido, northern Japan. Biological Conservation 108: 239-246.

Uchida, K., Takahashi, S., Shinohara, T. \& Ushimaru, A. 2016. Threatened herbivorous insects maintained by long-term traditional management practices in semi-natural grasslands. Agriculture, Ecosystems \& Environment 221: 156-162.

Uematsu, Y. \& Ushimaru, A. 2013. Topography- and management -mediated resource gradients maintain rare and common plant diversity around paddy terraces. Ecological Applications 23: 1357-1366.

Ushimaru, A., Uchida, K. \& Suka, T. 2018. Grassland biodiversity in Japan: threats, management and conservation. In: Squires, V.R., Dengler, J., Feng, H. \& Hua, L. (eds.) Grasslands of the world: diversity, management, and conservation, pp. 197-218. CRC Press, Boca Raton, US.

Venterink, H.O., Wassen, M.J., Verkroost, A.W.M. \& Ruiter, P.C.D. 2003. Species richness-productivity patterns differ between $\mathrm{N}$ -, P-, and K-limited wetlands. Ecology 84: 2191-2199.

Wassen, M.J., Venterink, H.O., Lapshina, E.D. \& Tanneberger, F. 2005. Endangered plants persist under phosphorus limitation. Nature 437: 547-550.

Watson, A. 1985. Soil erosion and vegetation damage near ski lifts at Cairn Gorm, Scotland. Biological Conservation 33: 363-381.

Wesche, K., Ambarlı, D., Kamp, J., Török, P., Treiber, J. \& Dengler, J. 2016. The Palaearctic steppe biome: a new synthesis. Biodiversity and Conservation 25: 2197-2231.

Wipf, S., Rixen, C., Fischer, M., Schmid, B. \& Stoeckli, V. 2005. Effects of ski piste preparation on alpine vegetation. Journal of Applied Ecology 42: 306-316.

Yonekura, K. \& Kajita, T. 2003. BG Plants: index of Japanese names and scientific names (YList). URL: http://ylist.info/ index.html. [in Japanese] 


\section{Photo Competition}

\section{Best Shots on "Grassland close-up"!}

Here the three winners of the EDGG Photo Competition!

The Jury of the Photo Competition was composed by Edy Fantinato, Magdalena Firganek-Fulcher, Anna Kuzemko, Rocco Labadessa, Jim Martin \& Jalil Noroozi

\section{$1^{\text {st }}$ place:}

\section{Reviews from the Jury:}

"Just gorgeous. A beautiful, monochromatic composition with an excellent control of the depth of field"

"In this picture, the golden sunlight reveals the preciosity and fragility of grassland biodiversity"

"The unusual colour scheme of this photo in warm colours, as well as the unusual fluffy texture of the pasque flower and the background makes this picture not just an image of a plant, but rather an image of an invisible world, on the border of reality a nd fantasy"

\section{Pulsatilla alpina in Safiental, Switzerland.}

Taken with Canon EOS 5D Mark III, Lens Canon EF 400mm f/2.8L IS II USM (1/800s at f/7.1 ISO 800). 


\section{$2^{\text {nd }}$ place}

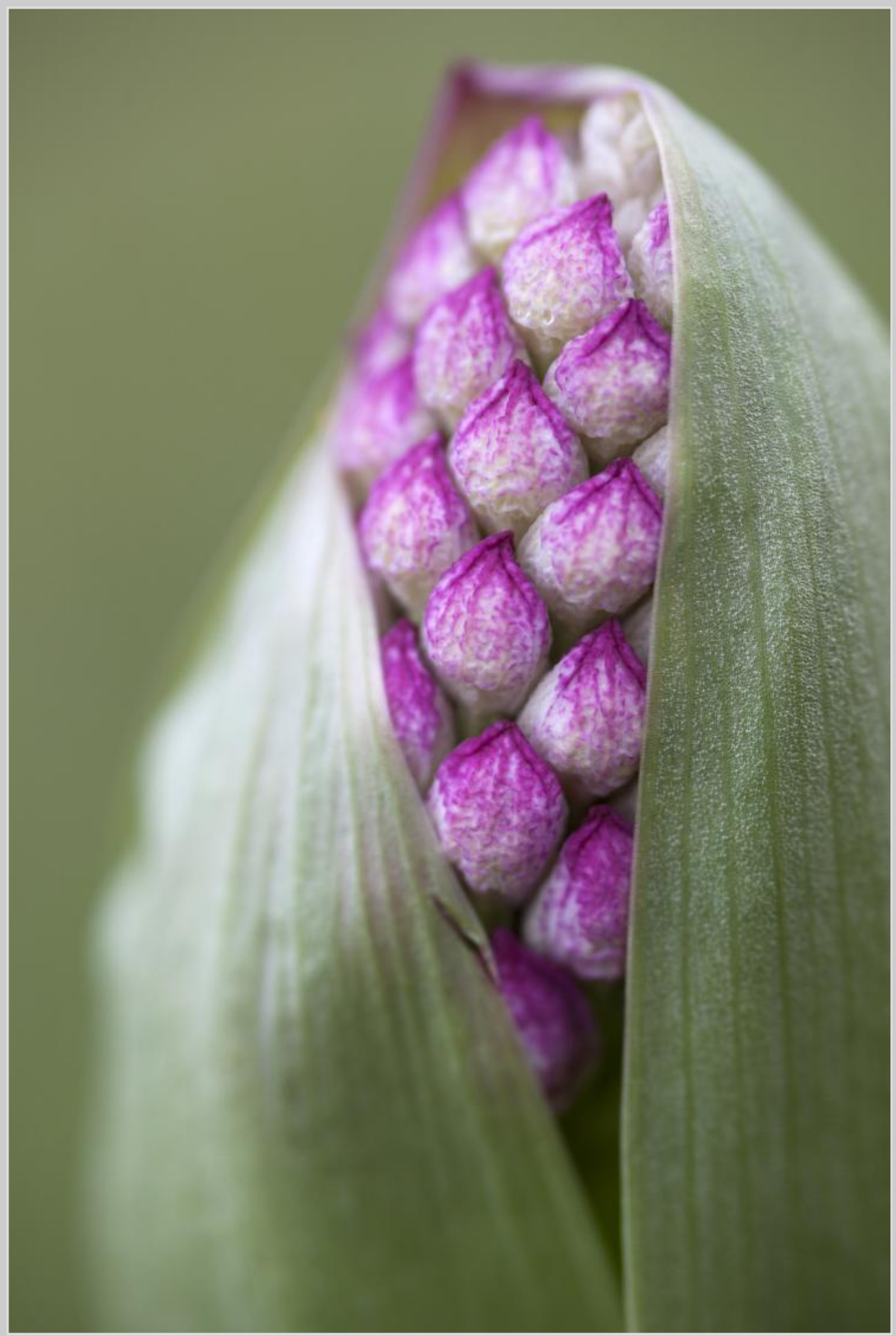

Reviews from the Jury:

"A beautiful closeup, almost like an abstract painting. I love the colours and the details."

"The hidden beauty of grasslands reveals itself only to sensitive and caring people"

"If one take a close look at the grassland, it is possible to see not only the phenomena but also the processes. In any case, the process of birth of an orchid flower, which the author of the photo caught, is very easy to overlook, but when you notice it, it truly fascinates"

Orchis $\mathrm{x}$ hybrida (O. militaris x O. purpurea) in the Natura 2000 "Katy" site, SE Poland. Taken with Canon EOS 5D Mark II (1/320s at f/3.5 ISO 200). 


\section{$3^{\text {rd }}$ place}

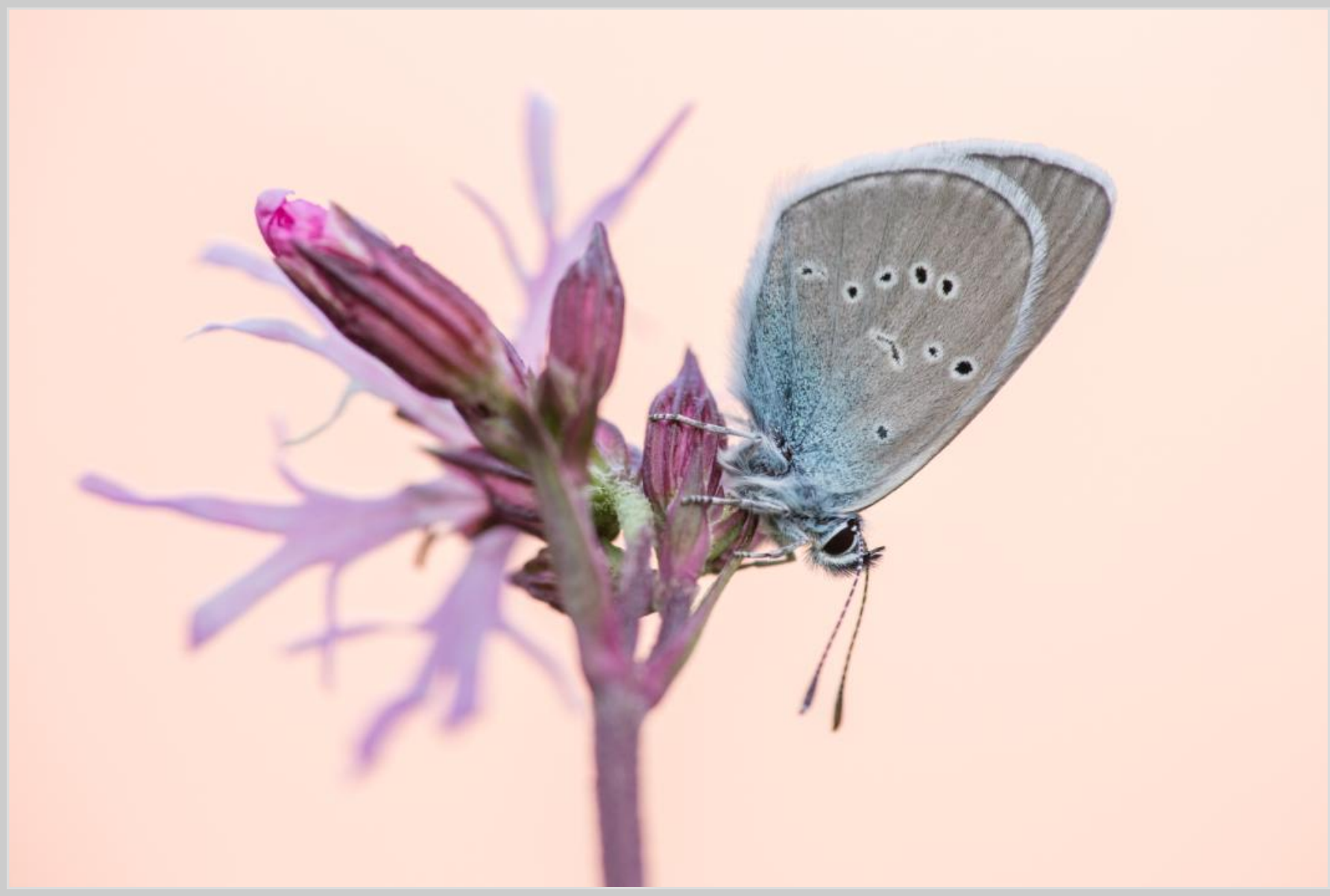

\section{Reviews from the Jury:}

"Flowers like butterflies and butterflies like flowers; this picture captured the delicacy of grassland inhabitants"

"Sometimes a close examination of grasslands allows us to see its integrity, even in those cases when this integrity is an il lusion. In this case, the butterfly is seen by the flower element and this illusion is enhanced by the colour of the photo, sustained in delicate pink and blue tones inherent in the most beautiful grassland flowers"

"A very clean and sharp image. I love how the shape of the butterfly complements the shape of the flower"

\section{Polyommatus semiargus sitting on Silene flos-cuculi. Rüti ZH, Switzerland.}

Taken with Canon EOS 5D Mark III, Lens: Sigma 180 mm F2,8 EX APO Macro OS HSM (1/25s at f/4.5, ISO 800). 


\section{Short Contributions}

\section{Expansion of the network of protected areas in Ukraine}

April 11, 2019 was a great day in the conservation of nature in Ukraine. On this day, 12 protected areas were created or enlarged. Six new reserves were created: National Natural Park "Nobelskyi" (Rivne region, 25318.8 ha), National Natural Park "Kamianska Sich" (Kherson region, 12261.1 ha), National Natural Park "Boikivshchyna" (Lviv region, 12240 ha), Landscape Reserve "Bazavlutskyi coastal -river complex" (Dnipro region, 3538.1 ha), Botanical Reserve "Zholoby" (Ternopil region, 60 ha) and Hydrological Reserve "Prymorskyi" (Zaporizhzhia region, 13115 ha). Six reserves were enlarged: National Natural Park "Synevyr" (Zakarpattia region, +3778.8 ha), National Natural Park "Zacharovanyi Krai" (Zakarpattia region, +4350.4 ha), Uzhanskyi National Natural Park (Zakarpattia region, +6988.0 ha), National Natural Park "Oleshkivski Pisky" (Kherson region, +3650.7 ha), National Natural Park "Biloberezhzhia Sviatoslava" (Mykolaiv region, +136.2 ha), Landscape Reserve "Tarasiv obrii" (Cherkasy region, 311 ha). On April 17, 2019, the extent of another protected area was enlarged - National Natural Park "Dnistrovskyi Kanion" (Ternopil region, +901.1 ha). In total, the area of protected land was increased by more than 80,000 hectares $(0.13 \%$ of the total areat of Ukraine) in nine regions of the country.

Steppe ecosystems are represented in four of the reserves: National Natural Parks "Kamianska Sich", "Oleshkivski Pisky", "Biloberezhzhia Sviatoslava" and Botanical Reserve "Zholoby".

The National Natural Park "Kamianska Sich" is located in the southern part of Ukraine in the Beryslav district of the Kherson region (Moysiyenko 2017). The new protected

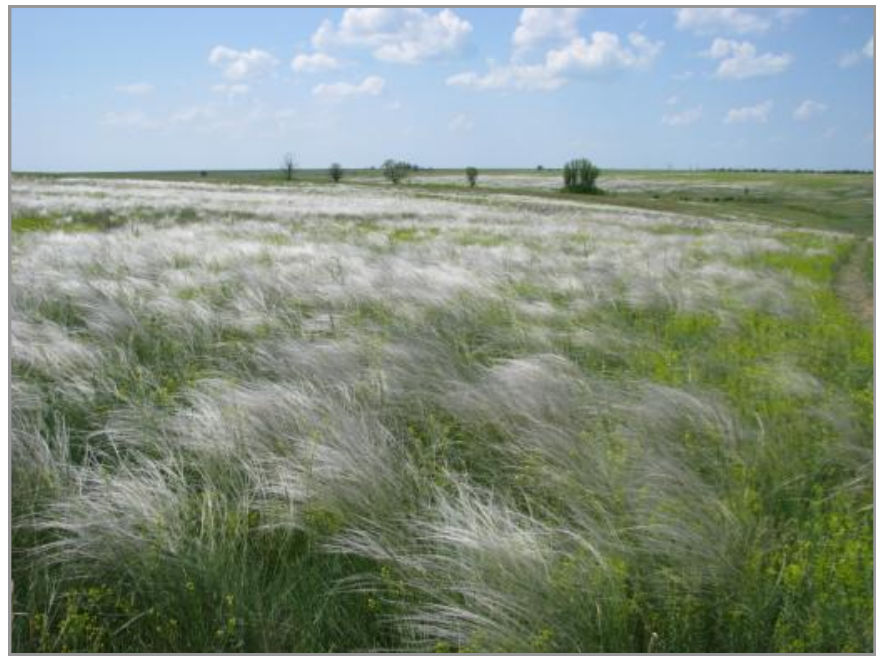

Steppes in the National Natural Park "Kamianska Sich". Photo: I. Moysiyenko. area contains many ravines, the Dnipro River's terrace and the Kakhovka Reservoir. The park is located in the Grass Steppe zone. The steppes are the dominant type of vegetation in the park, and there are also limestone outcrops, meadows, deciduous thickets, artificial woodlands, and so on; the Kakhovka Reservoir provides a significant area of open water habitat. The greater part of the protected area is occupied by the habitats of Resolution 4 of the Bern convention. There are more than 500 species of vascular plants, among them 46 rare species (including Astragalus dasyanthus Pall., A. ponticus Pall., Elytrigia stipifolia (Czern. ex Nevski) Nevski, Jurinea cyanoides (L.) Rchb., Ornithogalum boucheanum (Kunth) Asch., Stipa capillata L., S. lessingiana Trin. \& Rupr., S. pulcherrima K.Koch, S. ucrainica P.Smirn., Tulipa biebersteiniana Schult. \& Schult. f. s.I., T. gesneriana L., etc.). Eight communities of the Green Book of Ukraine are present. The reserve is important for habitats included in Resolution 4 of the Bern Convention (E1.2. Perennial calcareous grassland and basic steppes and F3.247 PontoSarmatic deciduous thickets).

The National Natural Park "Oleshkivski Pisky" was created in 2010. The park is situated on the sand massive along the left bank of Lower Dnipro river in Oleshky district, Kherson region (Moysiyenko 2012b). The park extent was increased by almost 1.5 times in 2019 and now stands at 11671.1 ha. The increase in extent took place in the Kozakhelagerska arena. The landscape is dominated by sandy steppe and dunes, with occasional depressions containing meadows, wetlands, and grove of birch. Both typical and rare vegetation types are conserved here, with endemic and relict higher plant species, including Betula borysthenica Klokov, Centaurea breviceps Iljin., Alyssum savranicum Andrz. and Agropyron dasyanthum Ledeb., ets.

The National Natural Park "Biloberezhzhia Sviatoslava" is located in the southern part of Ukraine, on the Kinburn

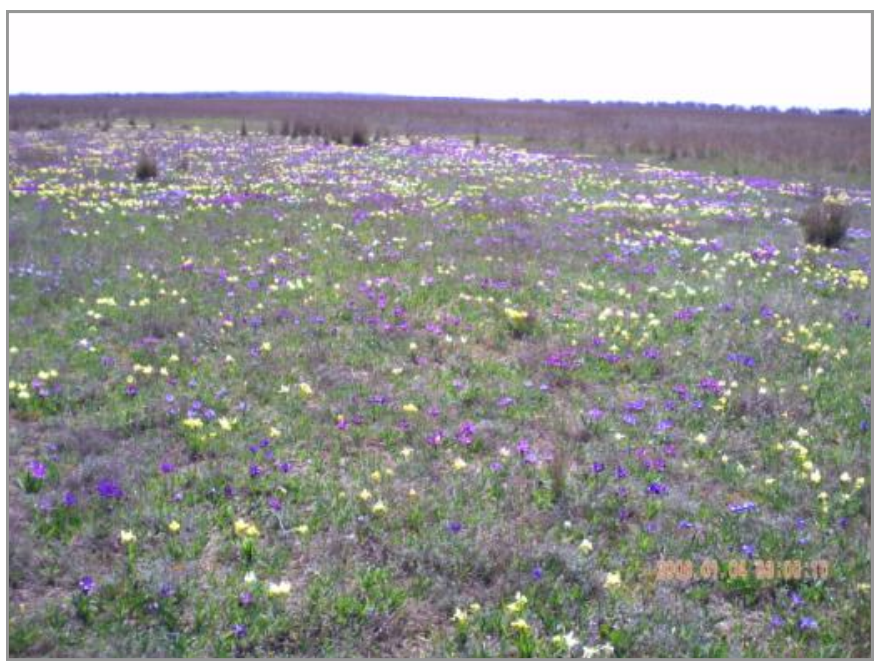

Iris pumila blossom in the National Natural Park "Biloberezhzhia Sviatoslava" Photo: V. Chaus. 
peninsula (Ochakiv district, Mykolaiv region). The Park was created in 2009 (Moysiyenko 2012a) and covers 35223.2 ha, extended by 136.2 ha. The vegetation cover of the additional area is dominated by coastal dunes, halophytic vegetation in the central part of the site and saline steppes on the most elevated area. The vegetation cover of the saline steppe includes a complex of steppe (Festuca valesiaca Gaudin, Artemisia austriaca Jacq., Iris pumila L., Convolvulus lineatus L., etc.) and halophytic (Artemisia santonica L., Limonium gmelinii (Willd.) O.Kuntze, etc.) species. Three lichen species are included in the Red Data Book of Ukraine: Cetraria aculeata (Schreb.) Fr. (= Cetraria steppae (Savicz) Karnef.), Seirophora lacunosa (Rupr.) Frödén and Xanthoparmelia camtschadalis (Ach.) Hale (Khodosovtsev at al. 2017).

The botanical reserve "Zholoby" is located in the western part of Ukraine in the Berezhany district of the Ternopil region (Olijar \& Protsiv 2012). It is situated in the foreststeppe zone, in a landscape dominated by semi-dry grasslands, plantations of Pinus sylvestris, natural deciduous woods and shrubs (Prunus spinosa, Crataegus spp.). The protected species Adonis vernalis L., Orchis militaris L. and Platanthera bifolia L. are present. The reserve has a significant area of the Carex humilis communities, which are included in the Green Book of Ukraine. The reserve is important for habitats included in Resolution 4 of the Bern Convention (E1.2. Perennial calcareous grassland and basic steppes and F3.1 Temperate thickets and scrub).

\section{References}

Khodosovtsev, A.Y., Darmostuk, V.V. \& Khodosovtseva, Y.A. 2017. The lichens and lichenicolous fungi of National Nature Park «Biloberezhzhia Svyatoslava». Chornomors'k. bot. z. 13 (3): 324 -332. [in Ukrainian.]

Moysiyenko, I.I. 2012a. National Natural Park "Biloberezhzhia Sviatoslava" in Onyshchenko, V.A. and Andrienko, T.L. (eds.). Phytodiversity of nature reserves and national nature parks of Ukraine 2: 27-43. [in Ukrainian.]

Moysiyenko, I.I. 2012b. National Natural Park "Oleshkivski Pisky" in Onyshchenko, V.A. and Andrienko, T.L. (eds.). Phytodiversity of nature reserves and national nature parks of Ukraine 2: 357372. [in Ukrainian.]

Moysiyenko, I.I. 2017. Sozofity proektovanoho natsionalnoho pryrodnoho parku "Kamianska Sich" [Sozophytes of the projected National Nature Park "Kamianska Sich"]. Nature protection in the steppe zone of Ukraine (to the 90th anniversary of the creation of the Nadmorsky reserves): Proceedings of the All -Ukrainian Scientific and Practical Conference (v. Urzuf, 14-15 March, 2017) 1: 271-280. [in Ukrainian.]

Olijar, G.I. \& Protsiv, G.P. 2012. Floristic features of some natural boundaries of Berezhany Opillya. Scientific Herald of NULES of Ukraine. Series: Forestry and Landscape Gardening 171 (1): 131 -134. [in Ukrainian.]

Ivan Moysiyenko, Kherson, Ukraine, ivan.moysiyenko@gmail.com

Olena Sadova, Kherson, Ukraine, sadova.npp@gmail.com

Galyna Olijar, Hrymailiv, Ukraine, h.olijar@gmail.com Vasyl Chaus, Ochakiv, Ukraine, nppbs@ukr.net

\section{Special issue of the journal Sustainability on semi- natural grasslands}

The special issue of the journal Sustainability "Impact of Management Changes on Semi-natural Grasslands and their Sustainable Use" is under preparation and EDGG members are invited to submit papers before 30 September 2019.

The semi-natural grasslands were established in a longterm process of interaction between man and nature and their existence fully depends on low-intensity farming (mostly grazing or mowing). Due to the combination of diverse site conditions, specific methods and the intensity of farming, a wide variety of grassland types have emerged. Agricultural intensification in the second half of the 20th century greatly affected semi-natural grasslands: their area was significantly reduced by conversion to arable land, forests, and urban areas; the structure of many remaining grasslands changed considerably due to intensive use, eutrophication, drainage, abandonment, and other pressures. Despite grassland conservation efforts, these processes are continuing.

The special issue aims to contribute to better knowledge on the consequences of changing management regimes to semi-natural grasslands and it should bridge the gap between agricultural production and grassland conservation. It will explore the effects of changes in grassland management regimes and intensity of farming or even its abandonment on the biodiversity, structure, and composition of semi-natural grasslands. Articles focusing on the impact of management changes on grassland functioning and ecosystem services provision are welcome as well. We also invite papers that discuss and document promising ways for maintenance of valuable semi-natural grasslands and the role of relevant policy instruments (such as the EU Common Agricultural Policy and Green Infrastructure Strategy) in achieving their sustainable use. The Special issue is now open for submissions with deadline on 30 September 2019. More information at: https://www.mdpi.com/journal/sustainability/ special issues/SeminaturalGrasslands.

\section{Lubos Halada, Nitra, Slovakia} lubos.halada@savba.sk

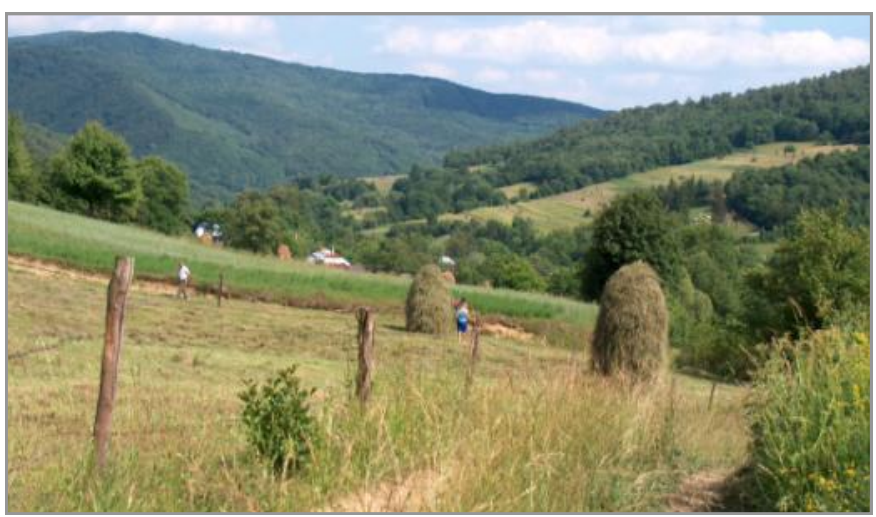




\section{Global overview on grassland diversity, management and conservation}

Squires, V.R., Dengler, J., Feng, H. \& Hua, L. (eds.) 2018. Grasslands of the World. Diversity, Management and Conservation. CRC Press, Boca Raton. 412 pp. Hardcover, ISBN 978-1-4987-9626-2. 135.50€.

Grasslands comprise one of the most extensive ecosystems of the world. They are present in most climatic zones, as natural grasslands in dry and/or cold climates (savannas, arctic-alpine, steppes) or azonal soils (saline, rocky, sandy...), as managed semi-natural grasslands in the zonal soils of forested biomes. However, most grassland types are seriously threatened, even though their conservation is essential not only because of their contribution to biodiversity and to ecosystem functioning, but also because they provide major ecosystem services, not least their use as pasture for feeding cattle, sheep and other domestic animals.

The increasing risks grasslands face encouraged the editors of this book to produce this updated review of the extent, diversity, ecology and management of grasslands worldwide, as well as their threat factors. After an introductory chapter about the origin and spread of grassland ecosystems, and their relationships with fire, grazing animals and humans, the book is organised in several chapters focused on regional grassland types, written by international teams of grassland experts.

The regional chapters are organised in two large sections. The first one consists of eight chapters devoted to Palaearctic grasslands (chapters 2-9), while the second one has six chapters describing grasslands from India, North America, Southern Africa, Eastern Africa, Southern America, and Australia (chapters 10-18). These two sections are by no means comparable. The Palaearctic section, contributed by the Eurasian Dry Grassland Group (EDGG), shows a high degree of consistency, starting with a synthesis (chapter 2) of the regional approach followed in the section, the main grassland types, and an overview of the current extent of and conservation issues affecting the major grassland

For EDGG members, this book is available with discount:

- For print copies $30 \%$ discount plus free delivery will be provided when you order at www.routledge.com with the code "EDGG30"

- For e-books and larger numbers of print copies, bigger discount is available when you order at cis@tandf.co.uk and quote 'EDGG offer'

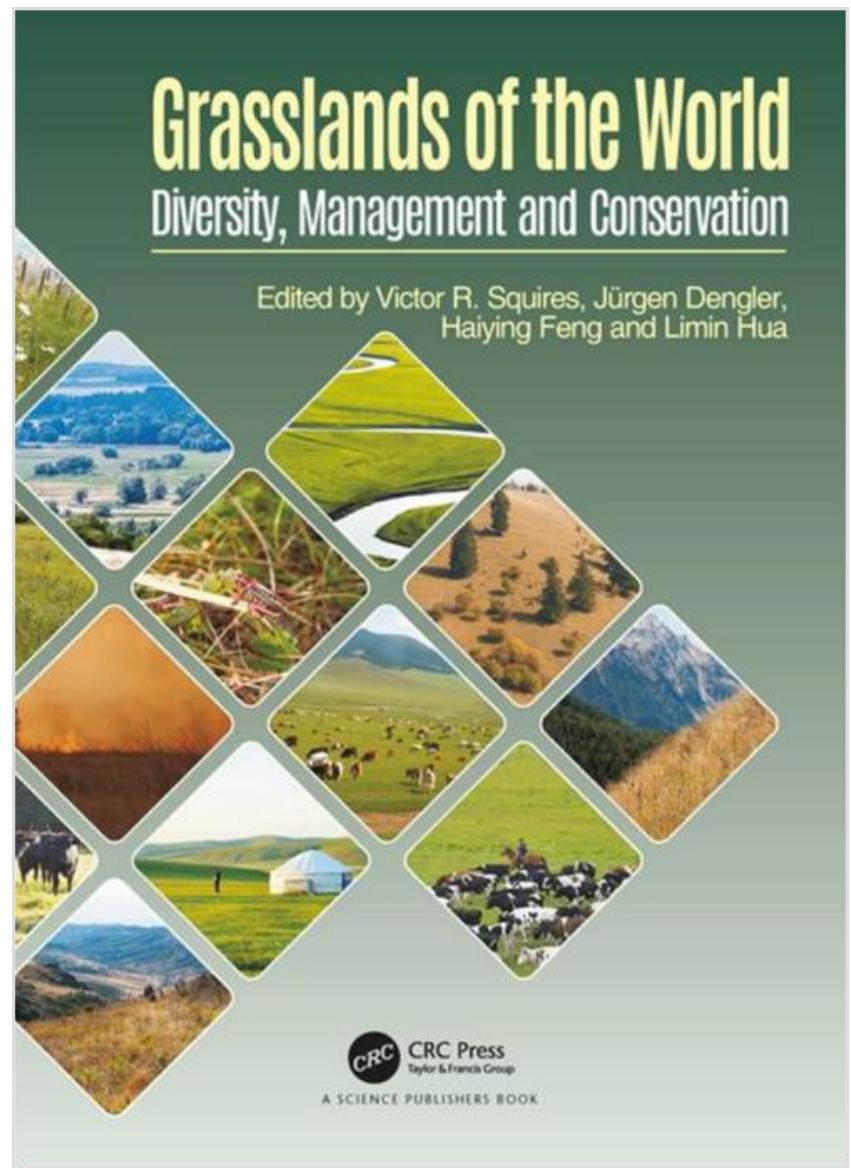

types across the seven regions covered: Western and Northern Europe, Eastern Europe, Mediterranean Basin, Russia, Kazakhstan and Central Asia, China and Mongolia and Japan. These chapters follow a similar pattern: they all provide a geographic context and describe the main grassland types focusing on their origin, naturalness, ecology and dominant grasses and herbs before subchapters devoted to Agronomic use, Value of grasslands (biodiversity, ecosystem services), Threats, Conservation and, finally, Management and Restoration.

The six chapters focused on the grasslands of America, Africa, India and Australia show varying degrees of complexity. In general, they aim at a similar organisation of subsections, but the information contained in these chapters is not at the same level. First of all, grassland typology is not so consistent as in Palaearctic chapters; in some cases it is mostly based on agronomic criteria, and therefore not so informative for grassland ecologists. Nevertheless, every bit of information is important, especially for those regions that so far lack up to date comprehensive 
reviews. Moreover, some chapters provide very valuable insights about aspects of these grasslands that are otherwise inaccessible for the international community. As an example, I would like to highlight the subsection about Ethnic Grasslands in the Indian chapter, where old and natural grasslands linked to specific ethnic groups are described with regard to their ecology, geography, biodiversity, management and threats.

The book concludes with a section composed of three chapters dealing with a variety of issues related to grassland management and conservation. These include the impact of climate change on Chinese grasslands and the people depending on them (chapter 16), future prospects for North American grasslands regarding human society (chapter 17) and a final chapter summarising threats to grasslands and future perspectives (chapter 18).

Overall, this is a very useful book for all those interested in grasslands around the world, such as grassland ecologists, conservation biologists and practitioners. It is also a good starting point for a future consistent typology of grasslands at a global scale and for putting together all the issues related to their conservation and management.

Idoia Biurrun, Bilbao, Spain idoia.biurrun@ehu.es

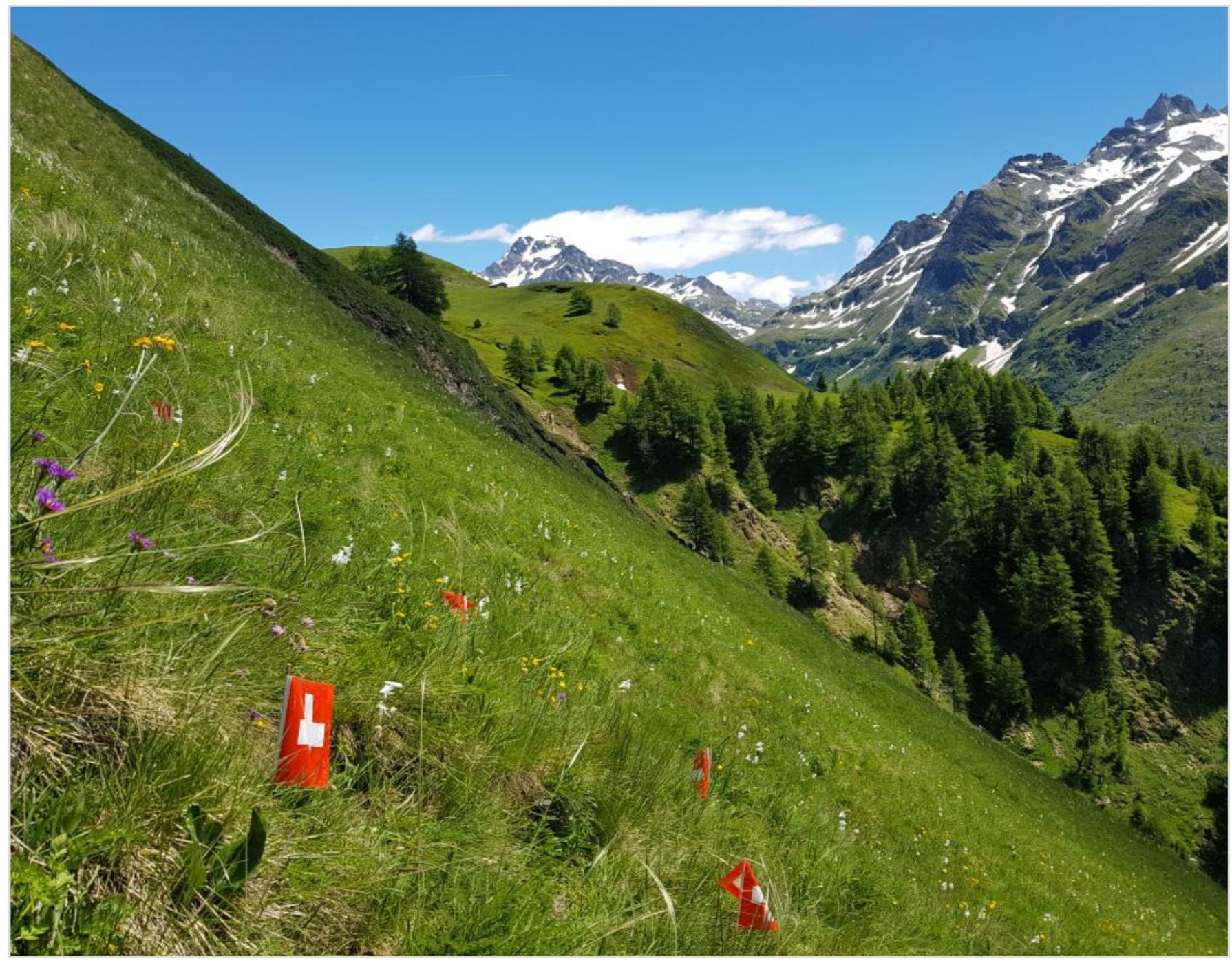

A $10 \mathrm{~m}^{2}$ plot with Paradisea liliastrum and Stipa pennata. Binntal, Canton Valais, Switzerland. Photo: S. Boch. 
Begerow, D., McTaggart, A. R. \& Agerer, R. (eds.) 2018. Basidiomycota and Entorrhizomycota [Syllabus of Plant Families: Adolf Engler's Syllabus der Planzenfamilien, 13th edn (Wolfgang Frey, ed.), Part 1(3).]. Stuttgart: Borntraeger Science Publishers. 471 pp. Hardcover, ISBN 978-3 -443-01098-0. $139 €$.

In its title and structure this book follows the tradition of the past century; meanwhile it attempts to clarify the systematic state of one very relevant group of fungi by summarising the most recent phylogenetic results. To date, the evolutionary relationships of fungi and fungi-like organisms have been accurately mapped from barcoding sequences and phylogenetic reconstructions (see Gaya et al. 2018); however, due to the early morphology-based perception and the legacy of early botanical works, the "nonphotosynthetic cryptogams" are still traditionally handled if they are "close" to the kingdom of plants (for example, mycological journals mostly list them under the category of "Plant Science" in scientific databases).

One of the early decisive botanical works was edited by Adolf Engler, the "Syllabus der Planzenfamilien", published in 1892. In line with the contemporary perception, fungi species (together with lichens) were discussed among plants, although only covered 21 pages. Since the first edition, treatment of this very diverse and heterogeneous group has expanded and now encompasses 1000 pages in the $13^{\text {th }}$ volume of the new series. The first volume of the new series was published in 2012 under the following title: "Blue-green Algae, Myxomycetes and Myxomycete-like organisms, Phytoparasitic protists, Heterotrophic Heterokontobionta and Fungi p.p." (Part 1/1, 178 pp., with 55 figures). This was followed by the second volume reviewing the phylum of sac fungi (Ascomycota), which was published in 2016 (Part 1/2, 322 pp., with 8 figures and 16 colour plates). The current volume of the series discusses another large phylum of the Dykaria group, the Basidiomycota, as well as the Entorrhizomycota phylum which was formerly separated from it (see Bauer et al. 2015). The latter has no sufficiently clear systematic state (Spatafora et al. 2017; Hibbet et al. 2018). It contains only two small genera, Entorrhiza and the monotypic Talbotiomyces; both are root parasites, with the former infesting members of Cyperaceae and Juncaceae worldwide. The Basidiomycota are an economically important and extremely diverse group of Fungi (viz. mushrooms, smuts, rusts, yeasts, etc.), with c. 36.000 species, $35 \%$ of the described species of true Fungi. In the case of such a diverse group with a very large species number it is a huge task to review and summarise the most recent phylogenetic results. Despite this, the work was undertaken by just three mycologists. The Agaricomycotina subdivision, containing $80 \%$ (1481 gen.) of all the genera, was prepared by Reinhard Agerer alone, while

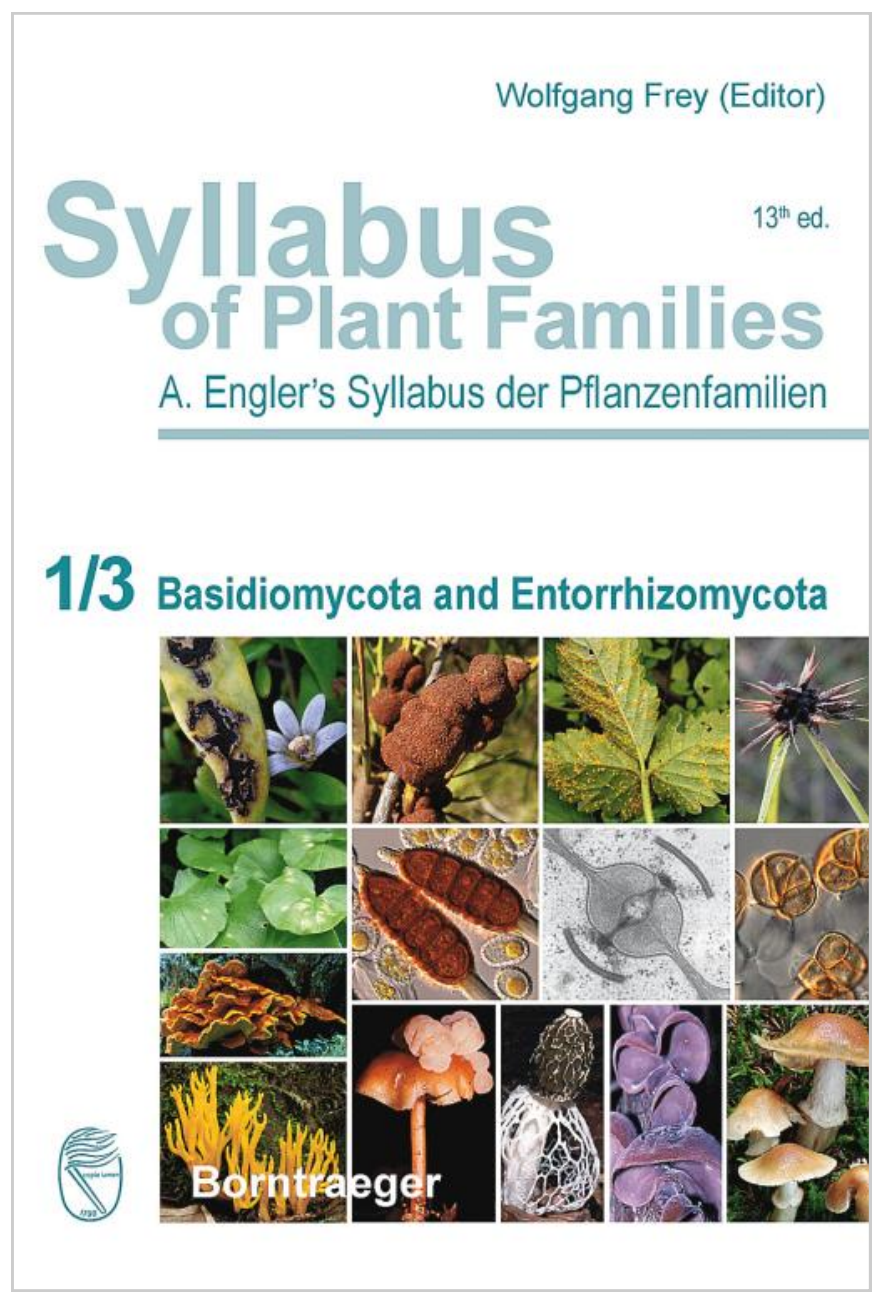

Domink Begerow and Alistair McTaggart produced the other three sections (Pucciniomycotina, Ustilaginomycotina and Entorrhizomycota).

Following an order-level synopsis, the volume presents the two phyla in systematical order, where the genus is the lowest shown taxonomical unit. In addition to morphological traits, the species belonging to the genera, their lifestyles and their distributions are all discussed. In several cases there are further remarks, notes and relevant citations in the text. Although the references are listed after every subdivision, for many taxa it is not clear which literature is the source of a given information (e.g. background of the taxonomical acceptance of the genus, its species number, description of its morphological traits), or which systematic concept was followed. In contrast to the former volume of Ascomycota, in this work the synonym names are not mentioned; furthermore it would have been helpful to indicate the years after the author names. While the type species are given for some of the groups, they are missing for Agaricomycotina. In most cases the genus concepts follow a rather narrow phylogenetic concept, but the acceptance of families is sometimes more conservative. 
Although such a synthesizing work can never be fully finished due to ongoing changes in the various systematic concepts and with newer results constantly being published, this volume should be a very effective tool in the hands of researchers working on applied mycology, and for experts interested in this group of fungi, as well as for teachers and students. Nowadays there are internet sites being developed based on a wider collaboration, that are intended to be used in a similar way to search for the modern systematic state of fungi (e.g. Index Fungorum), and some of these also provide morphological descriptions (e.g. MycoBank Database). However, there is no recent work containing up-to-date phylogenetic results concerning this group in book format, and edited based on a more or less uniform criteria system. Thus this volume should be on the shelf of every mycology institution and department, and of individuals who are interested in the systematics of the division Basidiomycota.

\section{References}

Bauer, R., Garnica, S., Oberwinkler, F., Riess, K., Weiß, M. \& Begerow, D. 2015. Entorrhizomycota: a new fungal phylum reveals new perspectives on the volution of fungi. PLOS ONE: 10(7): e0128183.

Gaya, E. et al. 2018. Fungal tree of life. In: K. J. Willis (ed.), State of the World's Fungi. Report. Royal Botanic Gardens, pp. 1217. Kew, UK.

Hibbett, D.S., Blackwell, M., James, T.Y., Spatafora, J.W., Taylor, J.W. \& Vilgalys, R. 2018. Phylogenetic taxon definitions for Fungi, Dikarya, Ascomycota and Basidiomycota. IMA Fungus 9 (2): 291-298.

Spatafora, J.W., Aime, M.C., Grigoriev, I.V., Martin, F., Stajich, J.E. \& Blackwell, M. 2017. The Fungal Tree of Life: from Molecular Systematics to Genome-Scale Phylogenies. MicrobiolSpectr. 5 (5): $1-32$.

Viktor Papp, Budapest, Hungary agaricum@gmail.com

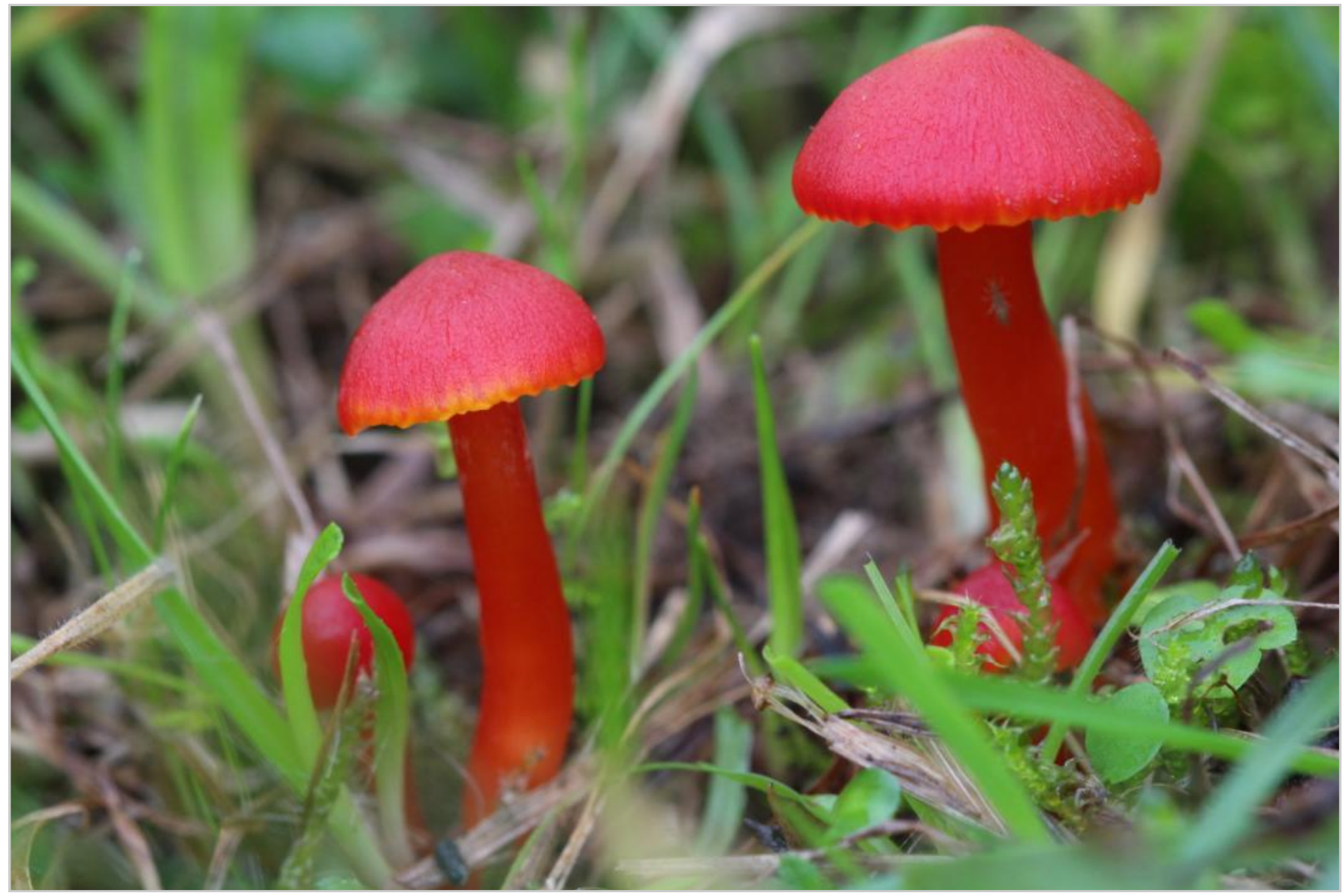

Scarlet waxcap (Hygrocybe coccinea), Hungary. Photo: P. Finy. 


\section{Book Review}

Rothero, E., Lake, S. \& Gowing, D. (eds.) 2016. Floodplain Meadows - Beauty and Utility. A Technical Handbook. Milton Keynes, Floodplain Meadows Partnership. Open University, UK. - available at http:// www.floodplainmeadows.org.uk/floodplain-meadowtechnical-handbook

The even mead, that erst brought sweetly forth

The freckled cowslip, burnet and green clover,

Wanting the scythe, all uncorrected, rank, Conceives by idleness, and nothing teems But hateful docks, rough thistles, kecksies, burs, Losing both beauty and utility.

These lines of Shakespeare from play Henry $V$ were not accidentally chosen by John Rodwell as an epigraph to the Preface to this book, since their last line contains the leitmotif of the entire book, also reflected in its title. It is beauty, which also implies biodiversity, as well as the economic utility of the meadows, which are the main subjects covered in the reviewed handbook.

The book consists of 11 chapters. The introductory chapter (Chapter 1) explains what floodplain meadows are, and also introduces the objective of this book - namely to raise awareness of the sensitivity of floodplain-meadow plant communities to changes in water level, management and soil fertility to help conserve the few remaining speciesrich floodplain meadows. In the next three chapters, the main components of floodplain meadows are characterized - wildlife, including plant communities, plant species, invertebrates, birds, mammals (Chapter 2), the origin and history of floodplain meadows, as well as changes in society's views on the value of meadows at different times (Chapter 3), major threats and conservation status, the role of the EU Habitats Directive and especially the contribution of the Floodplain Meadows Partnership to floodplain meadow conservation (Chapter 4). The next few chapters are devoted to the edaphic and hydrological features of floodplain meadows - soils (Chapter 5 ), nutrients (Chapter 6), water regime (Chapter 7). Special attention is paid to how to practically characterise thesefunctions, with particular emphasis on the indicative properties of plants. Chapter 8 describes the main plant communities of British floodplain meadows, in accordance with National Vegetation Classification (Rodwell 1992) - Burnet floodplain meadow (MG4): Alopecurus pratensisSanguisorba ofcinalis grassland, Kingcup-carnation sedge meadow (MG8): Cynosurus cristatus-Carex panicea-Caltha palustris grassland, Sedge Lawn (MG14): Carex nigraAgrostis stolonifera-Senecio aquaticus grassland, Meadowsweet sub-community (MG6d) of MG6 Ryegrass pasture: Lolium perenne-Cynosurus cristatus grassland, Cuckooflower grassland (MG15p): Alopecurus pratensisPoa trivialis-Cardamine pratensis grassland (provisional)

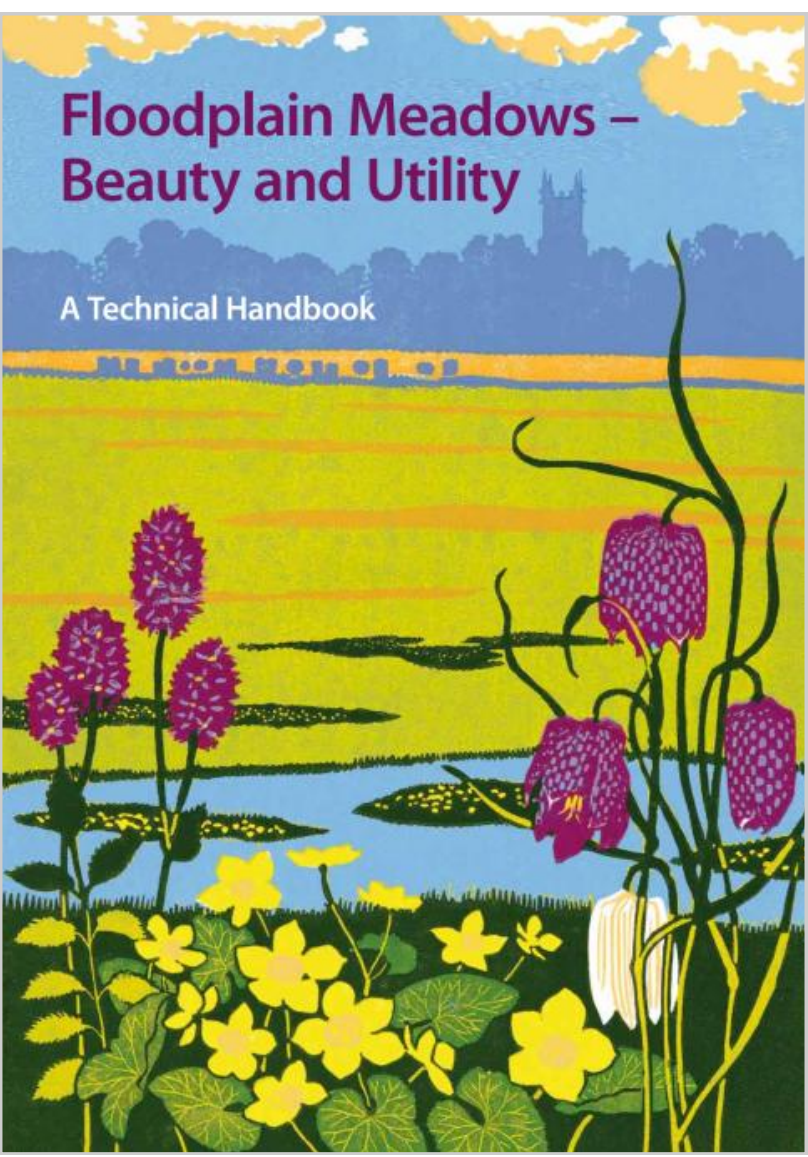

andFoxtail plash (MG13): Agrostis stolonifera-Alopecurus geniculatus grassland. Almost all of the characterized types include several sub-communities. The key section is Chapter 9, which deals with the detailed management of floodplain meadows, including its purpose and main practices. It is constantly emphasized that management must be flexible and be sensitive to site-specific circumstances. The impact of management on wildlife - invertebrates, birds and mammals is also considered. Other specific topics in this chapter include managing conflicts of interest and the economic value of a hay crop. Chapter 10 is dedicated to the topic of floodplain meadow restoration and creation . It provides justification for such activity, as well as a simple assessment system that allows the user to choose the optimal restoration or creation methodfor a particular site. It should be especially emphasized that in this chapter there is a subsection outlining the funding options for such activities. The last chapter (Chapter 11) describes how to carry out investigations and monitoring, as key elements of floodplain-meadow management and restoration. It describes in detail how to properly set out transect lines with monitoring quadrats using the standard method and how to carry out investigations using standard protocols.

Case studies are presented at the end of each chapter and illustrate and reinforce the information provided therein. The handbook is profusely illustrated with photographs, charts and diagrams. The abundance of hyperlinks makes it 
easy to access many related information resources. At first glance, the initial perception of the book from the perspective of a non-English reader is the drawback that the names of plants and animals are only given in English. However, the authors have solved this problem by placing a nomenclature list in the end of the book, that provides both the English and Latin names of plants, mammals, birds, invertebrates. In addition, a list with matching British classification units and European phytosociological associations is provided. The glossary of basic terms given at the end of the book will be useful to a wide range of readers. Of particular value for botanists and ecologists is an Ap- pendix, that provides the characteristics of other plant communities of floodplains, including species-poor grasslands, mires, swamps and ephemeral communities that are not described in detail in the book.

In my opinion, this book will be of interest to everyone who is engaged in the study and management of floodplain meadows, not only in the UK, but also abroad.

Anna Kuzemko, Kyiv, Ukraine, anyameadow.ak@gmail.com

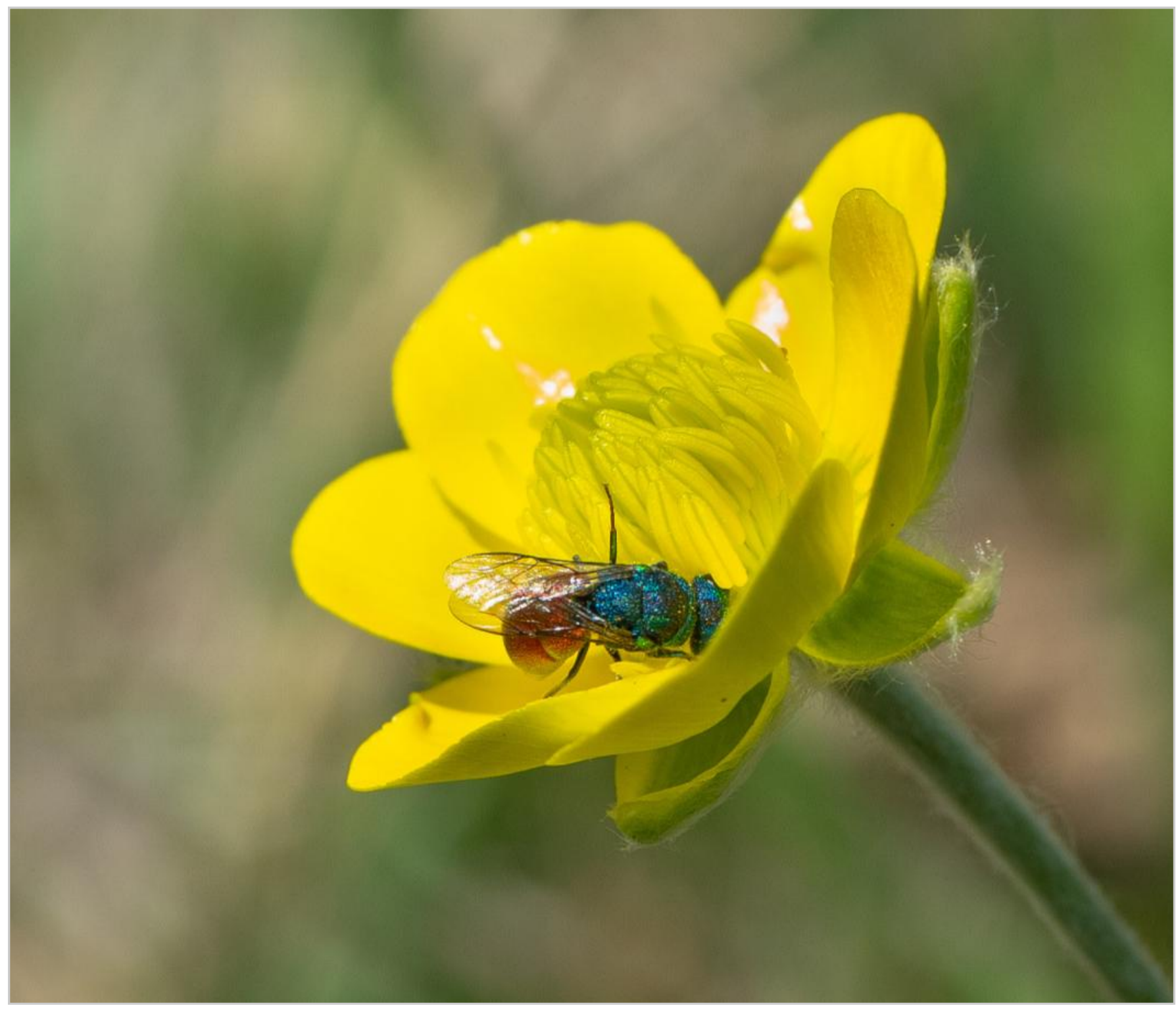

Ranunculus illyricus pollinated by a cuckoo-wasp (family Chrysididae). Photo: M. Janišová. 


\section{Recent Publications of our Members}

In this section, the contents of which will also be made available via our homepage, we want to facilitate an overview of grassland-related publications throughout Eurasia and to improve their accessibility. You are invited to send lists of such papers from the last three years following the format below to Iwona Dembicz, iwodem@op.pl. We will include your email address so that readers can request a pdf. For authors who own full copyright, we can also post a pdf on the EDGG homepage.

\section{Conservation and restoration}

Cwener, A., Chmielewski, P. \& Osek-Bodzak, M. 2018. State of Adonis vernalis (Ranunculaceae) populations in the Lublin region. Fragmenta Floristica et Geobotanica Polonica 25(2): 193-203.

Plenk, K., Bardy, K., Höhn, M. \& Kropf, M. 2019. Long-term survival and successful conservation? Low genetic diversity but no evidence for reduced reproductive success at the north-westernmost range edge of Poa badensis (Poaceae) in Central Europe. Biodiversity and Conservation 28: 12451265.

Zarzycki, J. 2018. Burning hay as a tool in conservation of mountain grassland vegetation in protected areas. Acta Scientiarum Polonorum. Formatio Circumiectus 17: 195204.

\section{Ecology}

Molnár, V.A., Mészáros, A., Csathó, A.I., Balogh, G. \& Csősz, S. 2018. Ant species dispersing the seeds of the myrmecochorous Sternbergia colchiciflora (Amaryllidaceae). NorthWestern Journal of Zoology 14(2): 265-267.

\section{Methodology, classification, databases}

Bruelheide, H., Dengler, J., Jiménez-Alfaro, B., Purschke, O., Hennekens, S.M., Chytrý M., Pillar, V. D., Jansen, F., Kattge, J., Sandel, B., Aubin, I., Biurrun, I., Field, R., Haider, S., Jandt, U., Lenoir, J., Peet, R.K., Peyre, G., Sabatini, F.M., Schmidt, M., Schrodt, F., Winter, M., Aćić, S., Agrillo, E., Alvarez, M., Ambarlı, D., Angelini, P., Apostolova, I., Arfin Khan, M.A.S., Arnst, E., Attorre, F., Baraloto, C., Beckmann, M., Berg, C., Bergeron, Y., Bergmeier, E., Bjorkman, A. D., Bondareva, V., Borchardt, P., Botta-Dukt, Z., Boyle, B., Breen, A., Brisse, H., Byun, C., Cabido, M.R., Casella, L., Cayuela, L., Černý, T., Chepinoga, V., Csiky, J., Curran, M., Ćušterevska, R., Dajić Stevanović, Z., De Bie, E., De Ruffray, P., De Sanctis, M., Di- mopoulos, P., Dressler, S., Ejrns, R., Abd El-Rouf Mousa ElSheikh, M., Enquist, B., Ewald, J., Fagndez, J., Finckh, M., Font, X., Forey, E., Fotiadis, G., Garca-Mijangos, I., de Gasper, A.L., Golub, V., Gutierrez, A.G., Hatim, M. Z., He, T., Higuchi, P., Holubov, D., Hölzel, N., Homeier, J., Indreica, A., Isık Gürsoy, D., Jansen, S., Janssen, J., Jedrzejek, B., Jiroušek, M., Jürgens, N., Kącki, Z., Kavgac I, A., Kearsley, E., Kessler, M., Knollová, I., Kolomiychuk, V., Korolyuk, A., Kozhevnikova, M., Kozub, Ł., Krstonošić, D., Kühl, H., Kühn, I., Kuzemko, A., Küzmič, F., Landucci, F., Lee, M.T., Levesley, A., Li, C.-F., Liu, H., Lopez-Gonzalez, G., Lysenko, T., Macanović, A., Mahdavi, P., Manning, P., Marcen, C., Martynenko, V., Mencuccini, M., Minden, V., Moeslund, J.E., Moretti, M., Müller, J.V., Munzinger, J., Niinemets, Ü., Nobis, M., Noroozi, J., Nowak, A., Onyshchenko, V., Overbeck, G.E., Ozinga, W. A., Pauchard, A., Pedashenko, H., Peñuelas, J., Pérez-Haase, A., Peterka, T., Petř́k, P., Phillips, O.L., Prokhorov, V., Rašomavičius, V., Revermann, R., Rodwell, J., Ruprecht, E., Rūsiṇa, S., Samimi, C., Schaminée, J.H.J., Schmiedel, U., Šibík, J., Šilc, U., Škvorc, Ž., Smyth, A., Sop, T., Sopotlieva, D., Sparrow, B., Stančić, Z., Svenning, J.-C., Swacha, G., Tang, Z., Tsiripidis, I., Turtureanu, P.D., Ugurlu, E., Uogintas, D., Valachovič, M., Vanselow, K.A., Vashenyak, Y., Vassilev, K., Vélez -Martin, E., Venanzoni, R., Vibrans, A.C., Violle, C., Virtanen, R., von Wehrden, H., Wagner, V., Walker, D.A., Wana, D., Weiher, E., Wesche, K., Whitfeld, T., Willner, W., Wiser, S., Wohlgemuth, T., Yamalov, S., Zizka, G. \& Zverev, A. 2019. sPlot - a new tool for global vegetation analyses. Journal of Vegetation Science 30: 161-186.

Contact persons:

Piotr Chmielewski: pchmielewski4@wp.pl

András István Csathó: csatho@verge.hu

Jürgen Dengler: juergen.dengler@uni-bayreuth.de

Kristina Plenk: kristina.plenk@boku.ac.at Jan Zarzycki: jan.zarzycki@urk.edu.pl 


\section{Forthcoming Events}

13th EDGG Field Workshop: Grasslands of Armenia along the elevational gradient

26 June -7 July 2019, Armenia

See details on https://edgg.org/fieldworkshop2019

10th International Association for Landscape Ecology (IALE) World Congress

1-5 July 2019 in Milan, Italy

Conference website: http://www.iale2019.unimib.it/

62nd Annual Symposium of International Association for Vegetation Science (IAVS)

14-19 July 2019 in Bremen, Germany

Conference website: http://iavs.org/2019-Annual-

Symposium/Home.aspx

See details in issue 41, pp. $23-25$

SCB's 29th International Congress for Conservation Biology (ICCB 2019)

21-25 July 2019 in Kuala Lumpur, Malaysia

Conference website: https://conbio.org/mini-sites/iccb-

$\underline{2019 /}$

28th Workshop of Vegetation European Survey (EVS)

2-6 September 2019 in Madrid, Spain

Abstract submission deadline: 8 May 2019

Conference website: http://evs2019madrid.es/

\section{0th European Congress of Herpetology}

2-6 September 2019 in Milan, Italy

Conference website: http://seh-congress-2019.unipv.it/

49th Annual Meeting of the Ecological Society of Germany, Austria and Switzerland (GfÖ)

9-13 September 2019 in Münster, Germany

Conference website: https://www.gfoe-conference.de/

8th World Conference on Ecological Restoration

22-27 September 2019 in Cape Town, South Africa

Conference website: https://ser2019.org/

European workshop: Atlantic biogeographical chalk grasslands

18-20 September 2019 in Rouen, France

See details on http://ec.europa.eu/environment/nature/ $\mathrm{n}$ a t u r a $2000 / \mathrm{plat}$ orm/events/ atlantic biogeographical_chalk_grasslands.htm

"Lost world" in biodiversity studies: focus at the Earth's blank spaces

23-27 September 2019, Vladivostok, Russia

Conference website: http://www.geobotanica.ru/ symposium 2019
World Conference of the Ecosystem Service Partnership 21-25 October 2019 in Hannover, Germany, with UFZ/iDiv as co-organisers

Conference website: https://www.espconference.org/esp10

Meeting of the FAO-CIHEAM Networks on Sheep and Goats and Mediterranean Pastures

23-25 October 2019 in Meknes, Morocco

Abstract submission deadline: 27 February 2019

Full text submission deadline: 15 May 2019

Conference website: http://networks.iamz.ciheam.org/ meknes2019/en/index.php

\section{British Ecological Society Annual Meeting 2019}

10-13 December 2019 in Belfast, Northern Ireland

Conference website: https:// www.britishecologicalsociety.org/events/annual-meeting2019/

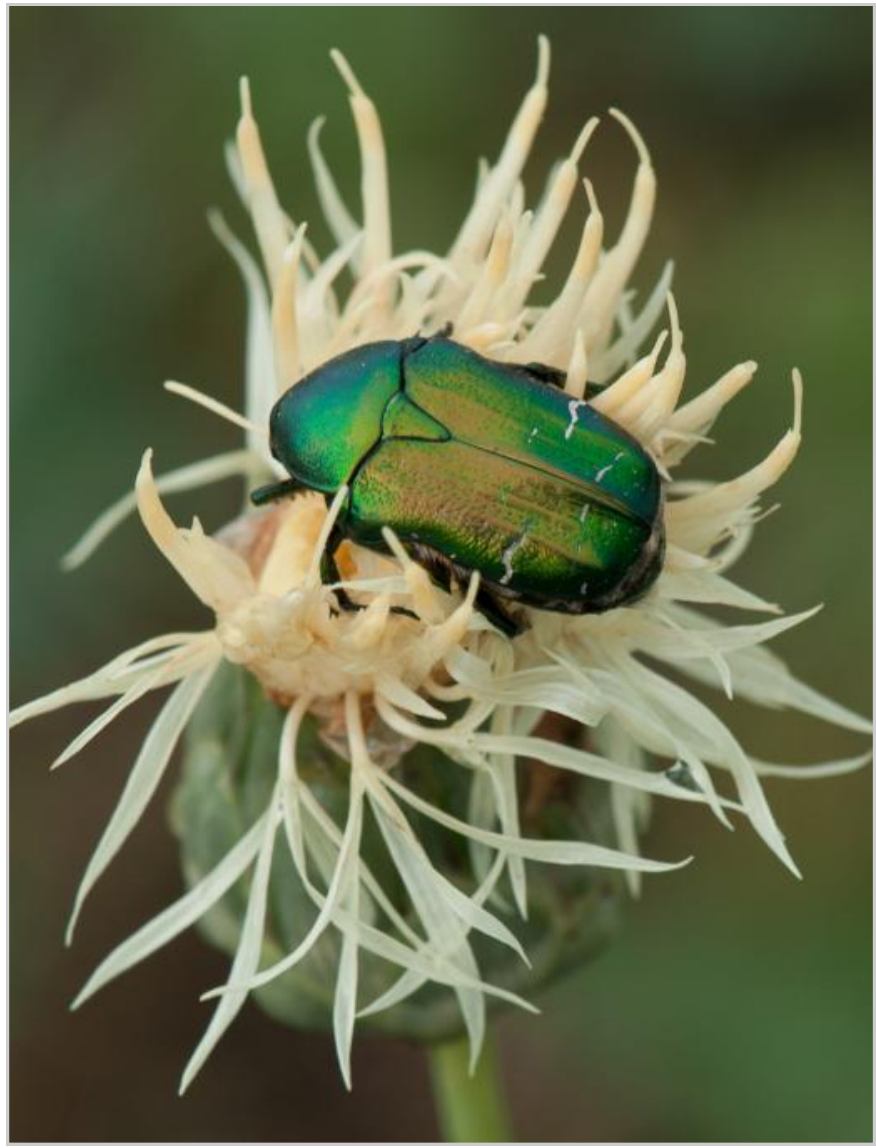

Cetonia aurata on Centaurea sp., Tula, Russian Federation. Photo: J. Dengler. 


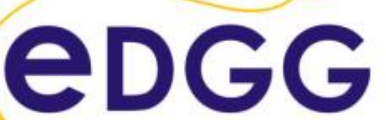

Grass[and] research and conservation
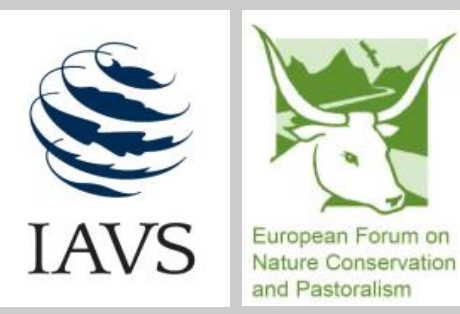

EDGG on the web:

http://www.edgg.org

EDGG in Facebook:

https://www.facebook.com/groups/938367279561202

EDGG on the Research Gate

https://www.researchgate.net/project/EDGG-Eurasian-

DryGrassland-Group

The Eurasian Dry Grassland Group (EDGG), founded in 2008, is a working group of the International Association for Vegetation Science (IAVS) and member of the European Forum on Nature Conservation and Pastoralism (EFNCP). On 13 June 2019 , it had 1299 members from 64 countries.

The Eurasian Dry Grassland Group (EDGG) is a network of researchers and conservationists interested in any type of Palaearctic natural and semi-natural grasslands. It is an official subgroup of IAVS (http://www.iavs.org) but one can join our group without being an IAVS member. We live from the activities of our members. Everybody can join the EDGG without any fee or other obligation.

The EDGG covers all aspects related to grasslands, in particular: plants - animals - fungi - microbia - soils - taxonomy - phylogeography - ecophysiology - population biology - species' interactions - vegetation ecology - syntaxonomy - landscape ecology - biodiversity - land use history - agriculture - nature conservation - restoration - environmental legislation - environmental education.

\section{EDGG Executive Committee and responsibilities of its members}

\section{Alla Aleksanyan, Armenia}

Chief Editor of the Website; Deputy Conference Coordinator; member of the Editorial Board of Palaearctic Grasslands

Didem Ambarlı, Germany,

didem.ambarli@gmail.com

Conference Coordinator; Deputy Chief Editor of the Website; member of the Editorial Board of Palaearctic Grasslands

Idoia Biurrun, Spain

idoia.biurrun@ehu.es

Membership Administrator; Deputy Chief Editor of Palaearctic Grasslands; Deputy Field Workshop Coordinator

Jürgen Dengler, Switzerland

juergen.dengler@uni-bayreuth.de

Secretary-General; Coordinator for Special Features; Deputy Chief Editor of Palaearctic Grasslands
Iwona Dembicz, Poland

Field Workshop Coordinator; member of the Editorial Board of Palaearctic Grasslands

Anna Kuzemko, Ukraine

anyameadow.ak@gmail.com

Chief Editor of Palaearctic Grasslands; Facebook Group Administrator

\section{Péter Török, Hungary}

molinia@gmail.com

IAVS Representative and Treasurer; Deputy Coordinator for Special Features; Deputy Secretary-General; member of the Editorial Board of Palaearctic Grasslands

\section{Stephen Venn, Finland}

stephen.venn@helsinki.fi

Deputy Facebook Group Administrator; member of the Editorial Board of Palaearctic Grasslands

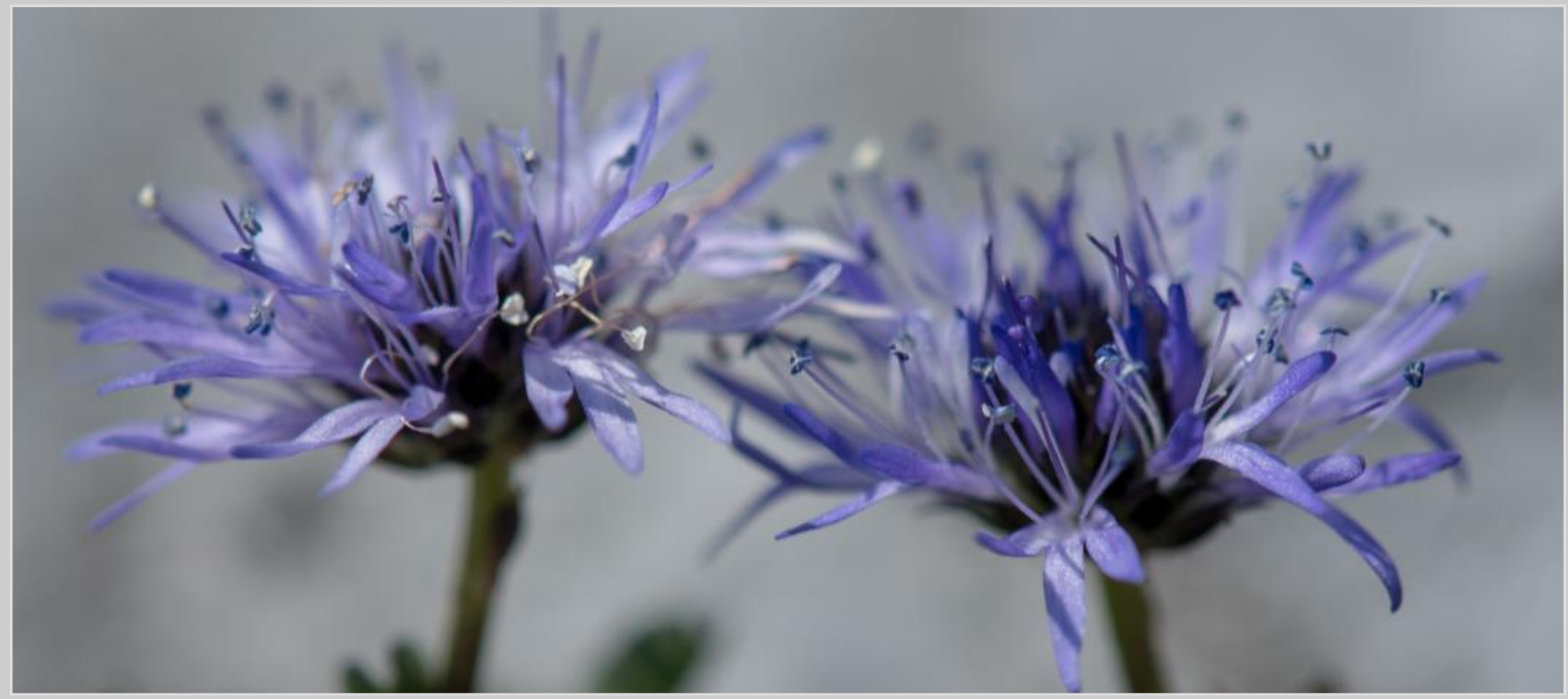

